\title{
Observation of new particle formation and measurement of sulfuric acid, ammonia, amines and highly oxidized organic molecules at a rural site in central Germany
}

\author{
Andreas Kürten, Anton Bergen, Martin Heinritzi, Markus Leiminger, Verena Lorenz, Felix Piel, Mario Simon, \\ Robert Sitals, Andrea C. Wagner, and Joachim Curtius \\ Institute for Atmospheric and Environmental Sciences, Goethe University Frankfurt, Frankfurt am Main, Germany
}

Correspondence to: Andreas Kürten (kuerten@iau.uni-frankfurt.de)

Received: 5 April 2016 - Published in Atmos. Chem. Phys. Discuss.: 6 June 2016

Revised: 26 September 2016 - Accepted: 27 September 2016 - Published: 14 October 2016

\begin{abstract}
The exact mechanisms for new particle formation (NPF) under different boundary layer conditions are not known yet. One important question is whether amines and sulfuric acid lead to efficient NPF in the atmosphere. Furthermore, it is not clear to what extent highly oxidized organic molecules (HOMs) are involved in NPF. We conducted field measurements at a rural site in central Germany in the proximity of three larger dairy farms to investigate whether there is a connection between NPF and the presence of amines and/or ammonia due to the local emissions from the farms. Comprehensive measurements using a nitrate chemical ionization-atmospheric pressure interface time-of-flight (CI-APi-TOF) mass spectrometer, a proton-transfer-reaction mass spectrometer (PTR-MS), particle counters and differential mobility analyzers (DMAs), as well as measurements of trace gases and meteorological parameters, were performed. We demonstrate here that the nitrate CI-APi-TOF is suitable for sensitive measurements of sulfuric acid, amines, a nitrosamine, ammonia, iodic acid and HOMs. NPF was found to correlate with sulfuric acid, while an anti-correlation with $\mathrm{RH}$, amines and ammonia is observed. The anti-correlation between NPF and amines could be due to the efficient uptake of these compounds by nucleating clusters and small particles. Much higher HOM dimer $\left(\mathrm{C}_{19} / \mathrm{C}_{20}\right.$ compounds) concentrations during the night than during the day indicate that these HOMs do not efficiently self-nucleate as no nighttime NPF is observed. Observed iodic acid probably originates from an iodine-containing reservoir substance, but the iodine signals are very likely too low to have a significant effect on NPF.
\end{abstract}

\section{Introduction}

The formation of new particles from gaseous compounds (nucleation) produces a large fraction of atmospheric aerosol particles (Zhang et al., 2012). While the newly formed particles have diameters between 1 and $2 \mathrm{~nm}$, they can grow and reach larger sizes, which enables them to act as cloud condensation nuclei (CCN, $\sim 50 \mathrm{~nm}$ in diameter or larger). Removal processes such as coagulation scavenging due to larger pre-existing particles can be important if the growth rates (GR) for the newly formed particles are slow and/or if the coagulation sink (CS) is high. The climatic effect of nucleation depends strongly on the survival probability of the newly formed particles, i.e., if they reach $\mathrm{CCN}$ size or not. Model calculations indicate that nucleation can account for ca. $50 \%$ of the CCN population globally (Merikanto et al., 2009). In addition to their climatic effect, secondary particles can also influence human health $(\mathrm{Nel}, 2005)$ or reduce visibility, e.g., in megacities (Chang et al., 2009).

New particle formation (NPF) is a global phenomenon and has been observed in many different environments (Kulmala et al., 2004). In most cases a positive correlation with the concentration of gaseous sulfuric acid has been observed ( $\mathrm{Si}$ hto et al., 2006; Kuang et al., 2008). However, other trace gases besides $\mathrm{H}_{2} \mathrm{SO}_{4}$ and $\mathrm{H}_{2} \mathrm{O}$ need to be involved in the formation of clusters, as otherwise the high particle formation rates measured in the boundary layer cannot be explained (Weber et al., 1997; Kirkby et al., 2011). One ternary compound which enhances the binary nucleation of sulfuric acid and water significantly is ammonia. However, at the relatively warm temperatures of the boundary layer the presence 
of ammonia is probably not sufficient for reaching the observed NPF rates when acting together with sulfuric acid and water (Kirkby et al., 2011; Kürten et al., 2016). The same applies for ion-induced nucleation (IIN); the observed IIN rates for the binary and ternary system including ammonia are not high enough to explain the observations (Kirkby et al., 2011). Therefore, recent nucleation experiments have focused on organic compounds acting as a ternary compound (besides $\mathrm{H}_{2} \mathrm{SO}_{4}$ and $\mathrm{H}_{2} \mathrm{O}$ ). Many studies indicate that amines have a very strong enhancing effect on nucleation (Kurtén et al., 2008; Chen et al., 2012; Glasoe et al., 2015). Indeed, a chamber experiment was able to show that the nucleation of sulfuric acid, water and dimethylamine (DMA) at $5{ }^{\circ} \mathrm{C}$ and $38 \% \mathrm{RH}$ produced particles at a rate which is compatible with atmospheric observations in the boundary layer over a relatively wide range of sulfuric acid concentrations (Almeida et al., 2013). For sulfuric acid concentrations $<10^{7}$ molecules $\mathrm{cm}^{-3}$, which is typical for the boundary layer, and dimethylamine mixing ratios of $>\sim 10 \mathrm{pptv}$, nucleation was found to proceed at or close to the kinetic limit. This means that every collision between sulfuric acid molecules and clusters associated with DMA leads to a larger cluster which does not evaporate significantly (Kürten et al., 2014).

In principle, mass spectrometry using nitrate chemical ionization could be used to detect neutral clusters consisting of sulfuric acid and bases in the atmosphere. However, only a few studies indicate that neutral nucleating atmospheric clusters consist of sulfuric acid and ammonia or amines (Zhao et al., 2011; Jiang et al., 2011), while other studies could not identify such clusters (Jokinen et al., 2012; Sarnela et al., 2015). A further outstanding issue is the question about the magnitude of the atmospheric amine mixing ratios at different locations. In the past several years, experimental tools for sensitive online measurement of amines in the pptv range have become available (Hanson et al., 2011; Yu and Lee, 2012). The reported amine levels reach from up to tens of pptv (Hanson et al., 2011; Freshour et al., 2014; You et al., 2014; Hellén et al., 2014) to <0.1 pptv (Sipilä et al., 2015). An important question is therefore whether some of the reported mixing ratios could be biased high or low due to instrumental issues, or whether the natural variability in the amine mixing ratios due to different source strengths can explain the differences.

Other possible contributors to particle formation are highly oxidized organic compounds (HOMs) originating, for example, from the reaction of monoterpenes with atmospheric oxidants (Zhao et al., 2013; Ehn et al., 2014; Riccobono et al., 2014; Jokinen et al., 2015; Kirkby et al., 2016; Bianchi et al., 2016). From this perspective it seems likely that different nucleation pathways are possible and may dominate at different sites depending, for example, on the concentration of sulfuric acid, amines, oxidized organic compounds and other parameters such as temperature and relative humidity. Synergistic effects are also possible; for example, it has been demonstrated that the combined effect of ammonia and amines can lead to more efficient particle formation with sulfuric acid and water than for a case where ammonia is not present (Glasoe et al., 2015). Due to the manifold possibilities for nucleation and the low concentrations of the growing clusters, it is challenging to identify the dominant particle formation pathway from field measurements in an environment where many possible ingredients for nucleation are present at the same time. However, such measurements are necessary and previous measurements from Hyytiälä, Finland, underscored the importance of sulfuric acid, organic compounds and amines regarding NPF (Kulmala et al., 2013).

In this study, we have chosen to conduct measurements with an emphasis on the observation of NPF at a rural site in central Germany. The goal of this field campaign was to measure NPF in an amine-rich environment in the vicinity of dairy farms, as cows are known to emit a variety of different amines as well as ammonia (Schade and Crutzen, 1995; Ge et al., 2011; Sintermann et al., 2014). The measurements were performed using different particle counters and particle size analyzers as well as trace gas $\left(\mathrm{O}_{3}, \mathrm{SO}_{2}\right.$ and $\left.\mathrm{NO}_{x}\right)$ monitors. A proton-transfer-reaction mass spectrometer (PTR-MS) is used to determine the gas-phase concentration of monoterpenes and isoprene, whereas a chemical ionization time-offlight mass spectrometer using nitrate primary ions (Jokinen et al., 2012; Kürten et al., 2014) is used for the measurement of sulfuric acid, amines, ammonia and highly oxidized organics.

\section{Methods and measurement site description}

\subsection{Measurement site description}

The measurement site is located right next to a meteorological weather station operated by the German Weather Service (DWD measurement station MichelstadtVielbrunn/Odenwald; $\quad 49^{\circ} 43^{\prime} 04.4^{\prime \prime} \mathrm{N}, \quad 09^{\circ} 05^{\prime} 58.9^{\prime \prime} \mathrm{E}$; $452 \mathrm{~m}$ a.s.l.). The village of Vielbrunn has a total of $\sim 1300$ inhabitants and is surrounded by fields and forests. The next larger cities are Darmstadt $(\sim 35 \mathrm{~km}$ to the WNW) and Frankfurt am Main $(\sim 50 \mathrm{~km}$ to the NNW). The site was chosen for several reasons: (i) three larger dairy farms are close by, which should possibly enable us to study the effect of amines on NPF; (ii) it can be regarded as typical for a rural or agricultural area in central Europe; (iii) the site is not too far away from the University of Frankfurt, which allowed for the station to be visited for instrument maintenance on a daily basis; and (iv) since we could measure right next to a meteorological station, infrastructure and meteorological data from the DWD could be used.

In terms of studying the effect of amines on NPF, we were expecting to see a direct effect due to the local emissions from the dairy farms. Each of these farms keeps a few hun- 
dred cows in shelters, which essentially consist of only a roof and a fence, such that the wind can easily carry away the emissions. As mentioned in the introduction, livestock are known to emit a variety of amines as well as ammonia (Schade and Crutzen, 1995; Sintermann et al., 2014), both of which should have an influence on NPF and growth (Almeida et al., 2013; Lehtipalo et al., 2016). The farms are located in the west ( $\sim 450 \mathrm{~m}$ distance), south-southwest $(\sim 1100 \mathrm{~m}$ distance) and southeast ( $\sim 750 \mathrm{~m}$ distance) of the station.

One further aspect that should be considered is the fact that the site is also surrounded by forests (mixed type of coniferous and deciduous trees, at least $1 \mathrm{~km}$ away). Consequently, emissions of, for example, monoterpenes $\left(\mathrm{C}_{10} \mathrm{H}_{16}\right.$ compounds) can also potentially influence NPF as recent studies indicate that their oxidation products can contribute to NPF and particle growth (Schobesberger et al., 2013; Riccobono et al., 2014; Ehn et al., 2014; Kirkby et al., 2016).

\subsection{CI-APi-TOF}

The key instrument for the data discussed in this study is the chemical ionization-atmospheric pressure interface time-offlight mass spectrometer (CI-APi-TOF). The instrument was first introduced by Jokinen et al. (2012), and the one used in the present study is described by Kürten et al. (2014). The CI-APi-TOF draws a sample flow of $8.5 \mathrm{slm}$ (standard liters per minute), which interacts with nitrate primary ions $\left(\left(\mathrm{HNO}_{3}\right)_{0-2} \mathrm{NO}_{3}^{-}\right)$within an ion reaction zone at ambient pressure ( $\sim 50 \mathrm{~ms}$ reaction time). The primary ions are generated from the interaction of $\mathrm{HNO}_{3}$ in a sheath gas and a negative corona discharge (Kürten et al., 2011). The ion source is based on the design by Eisele and Tanner (1993) for the measurement of sulfuric acid. The primary and product ions are drawn into the first stage of a vacuum chamber through a pinhole ( $\sim 350 \mu \mathrm{m}$ diameter). Quadrupoles in the first and a second stage of the chamber, operated in rf-only mode, are used to guide the ions. A lens stack in a third stage focuses and prepares the ions energetically before they enter the time-of-flight mass spectrometer (Aerodyne Research Inc., USA, and Tofwerk AG, Switzerland). This mass spectrometer has a mass resolving power of $\sim 4000 \mathrm{Th} / \mathrm{Th}$ and a mass accuracy of better than $10 \mathrm{ppm}$. These characteristics allow the elemental identification of unknown ions - i.e., different species with the same nominal (integer) $\mathrm{m} / \mathrm{z}$ ratio can be separated due to their mass defect. Using isotopic patterns for an expected ion composition supports the ion identification. For the data analysis the software tofTools (Junninen et al., 2010) is used within the Matlab environment.

Previous work has shown that the CI-APi-TOF can be used for highly sensitive measurements of sulfuric acid (Jokinen et al., 2012), clusters of sulfuric acid and dimethylamine (Kürten et al., 2014), organic compounds with very low volatility (Ehn et al., 2014) and dimethylamine (Simon et al., 2016). Sulfuric acid and its clusters can be detected after do- nating a proton to the primary ions, i.e.,

$$
\begin{aligned}
& \left(\mathrm{H}_{2} \mathrm{SO}_{4}\right)_{n}+\left(\mathrm{HNO}_{3}\right)_{m=0-2} \mathrm{NO}_{3}^{-} \\
& \rightarrow\left(\mathrm{H}_{2} \mathrm{SO}_{4}\right)_{n-1}\left(\mathrm{HNO}_{3}\right)_{k=0-2} \mathrm{HSO}_{4}^{-} \\
& +(m-k+1)\left(\mathrm{HNO}_{3}\right),
\end{aligned}
$$

whereas the low-volatility organic compounds (HOMs) are detected after clustering with $\mathrm{NO}_{3}^{-}$, i.e.,

$$
\begin{aligned}
& \mathrm{HOM}+\left(\mathrm{HNO}_{3}\right)_{m=0-2} \mathrm{NO}_{3}^{-} \\
\rightarrow & (\mathrm{HOM}) \mathrm{NO}_{3}^{-}+m\left(\mathrm{HNO}_{3}\right) .
\end{aligned}
$$

In both Reactions (R1) and (R2) the presence of water has been neglected for simplicity. The measurement of amines is possible because they can be associated with nitrate cluster ions (Sect. 3.6). Generally, the quantification of a substance is derived with the following equation:

$$
\begin{aligned}
& \text { concentration }= \\
& C \cdot \ln \left(1+\frac{\sum \text { product ion count rates }}{\sum \text { primary ion count rates }}\right) .
\end{aligned}
$$

Equation (1) relates the sum of the product ion count rates to the sum of the primary ion count rates. Using a calibration constant $C$, the concentration of a neutral substance can be determined. In the case of the sulfuric acid concentration $\left(\left[\mathrm{H}_{2} \mathrm{SO}_{4}\right]\right)$ the product ion count rates are due to $\mathrm{HSO}_{4}^{-}$and $\left(\mathrm{HNO}_{3}\right) \mathrm{HSO}_{4}^{-}$, while the primary ion count rates include $\mathrm{NO}_{3}^{-}$, $\left(\mathrm{HNO}_{3}\right) \mathrm{NO}_{3}^{-}$and $\left(\mathrm{HNO}_{3}\right)_{2} \mathrm{NO}_{3}^{-}$. The calibration constant has been determined as $6 \times 10^{9}$ molecules $\mathrm{cm}^{-3}$ (Kürten et al., 2012).

The same calibration constant has also been used for the quantification of HOMs. However, in this case the mass dependent transmission of the CI-APi-TOF was taken into account by the method of Heinritzi et al. (2016). This requires an additional correction factor in Eq. (1), which is around 0.4 for the $m / z$ range 300 to $400 \mathrm{Th}$ and 0.22 for the range 500 to $650 \mathrm{Th}$; these factors take into account only the transmission as a function of the $m / z$ value, while assuming the same ionization efficiency as for sulfuric acid, which has been shown to be a valid assumption by Ehn et al. (2014). The quantification of amines will be detailed in Sect. 3.6. Table 1 gives an overview of the identified ion signals used in the further analysis evaluating sulfuric acid monomer and dimer concentrations as well as amine, nitrosamine, ammonia and iodic acid signals (further explanations will be given in the following sections).

Regarding the loss of sample molecules within the inlet line of the CI-APi-TOF, we expect only a minor effect. As the sample line has a total length around $1 \mathrm{~m}$, a very high flow rate was applied over most of the inlet length (Berresheim et al., 2000). Only for the last $\sim 15 \mathrm{~cm}$ was the flow of $8.5 \mathrm{slm}$ applied when taking the sample from the central part of the first inlet stage, where the inlet has a significantly larger diameter $(5 \mathrm{~cm}$ instead of $1 \mathrm{~cm}$ for the last part) to avoid wall contact of the relevant portion of the sampled air. 
Table 1. List of ions used in the identification of sulfuric acid (monomer and dimer), iodic acid, ammonia, amines $\left(\mathrm{C}_{1}, \mathrm{C}_{2}, \mathrm{C}_{3}, \mathrm{C}_{4}\right.$ and $\left.\mathrm{C}_{6}\right)$ and dimethylnitrosamine. Cattle farms in the vicinity of the measurement site are expected to be a source for the listed amines (Ge et al., 2011).

\begin{tabular}{lll}
\hline Ion & Exact mass & Neutral compound \\
\hline $\mathrm{HSO}_{4}^{-},\left(\mathrm{HNO}_{3}\right) \mathrm{HSO}_{4}^{-}$ & 96.9601, & sulfuric acid monomer \\
& 159.9557 & \\
$\left(\mathrm{H}_{2} \mathrm{SO}_{4}\right) \mathrm{HSO}_{4}^{-},\left(\mathrm{HNO}_{3}\right)\left(\mathrm{H}_{2} \mathrm{SO}_{4}\right) \mathrm{HSO}_{4}^{-}$ & 194.9275, & sulfuric acid dimer \\
& 257.9231 & \\
$\mathrm{IO}_{3}^{-},\left(\mathrm{H}_{2} \mathrm{O}\right) \mathrm{IO}_{3}^{-},\left(\mathrm{HNO}_{3}\right) \mathrm{IO}_{3}^{-}$ & 174.8898, & iodic acid \\
& 192.9003, & \\
& 237.8854 & \\
& 142.0106, & ammonia \\
$\left(\mathrm{NH}_{3}\right)\left(\mathrm{HNO}_{3}\right)_{1,2} \mathrm{NO}_{3}^{-}$ & 205.0062 & \\
& 156.0262, & $\mathrm{C}_{1}$ amines (e.g., methylamine) \\
$\left(\mathrm{CH}_{5} \mathrm{~N}\right)\left(\mathrm{HNO}_{3}\right)_{1,2} \mathrm{NO}_{3}^{-}$ & 219.0219 & \\
& 170.0419, & $\mathrm{C}_{2}$ amines (e.g., ethylamine, dimethylamine) \\
$\left(\mathrm{C}_{2} \mathrm{H}_{7} \mathrm{~N}\right)\left(\mathrm{HNO}_{3}\right)_{1,2} \mathrm{NO}_{3}^{-}$ & 233.0375 & \\
& 184.0575, & $\mathrm{C}_{3}$ amines (e.g., trimethylamine, propylamine) \\
$\left(\mathrm{C}_{3} \mathrm{H}_{9} \mathrm{~N}\right)\left(\mathrm{HNO}_{3}\right)_{1,2} \mathrm{NO}_{3}^{-}$ & 247.0532 & \\
& 198.0732, & $\mathrm{C}_{4}$ amines (e.g., diethylamine, butylamine) \\
$\left(\mathrm{C}_{4} \mathrm{H}_{11} \mathrm{~N}\right)\left(\mathrm{HNO}_{3}\right)_{1,2} \mathrm{NO}_{3}^{-}$ & 261.0688 & \\
& 226.1045, & $\mathrm{C}_{6}$ amines (e.g., triethylamine) \\
$\left(\mathrm{C}_{6} \mathrm{H}_{15} \mathrm{~N}\right)\left(\mathrm{HNO}_{3}\right)_{1,2} \mathrm{NO}_{3}^{-}$ & 289.1001 & \\
& 199.0320, & dimethylnitrosamine \\
$\left(\mathrm{C}_{2} \mathrm{H}_{6} \mathrm{~N} \mathrm{~N}_{2} \mathrm{O}\right)\left(\mathrm{HNO}_{3}\right)_{1,2} \mathrm{NO}_{3}^{-}$ & 262.0277 & \\
& & \\
& &
\end{tabular}

\subsection{PTR-MS}

Volatile organic compounds (VOCs) were measured with a calibrated proton-transfer-reaction mass spectrometer (PTRMS using a quadrupole mass spectrometer, IONICON $\mathrm{GmbH}$, Innsbruck, Austria). The instrument inlet was heated to $60^{\circ} \mathrm{C}$ and the same temperature was applied to the ion drift tube. The drift tube was operated at an $E / N$ of $126 \mathrm{Td}$ in order to minimize the formation of protonated water clusters while maintaining a high sensitivity $(E / N$ is the ratio between the electric field strength $E$ in $\mathrm{V} \mathrm{cm}^{-1}$ and the number density $N$ of gas molecules in $\mathrm{cm}^{-3}$; see Blake et al., 2009).

A calibration of the instrument was performed prior to the campaign with a gas mixture containing several VOCs at a known volume mixing ratio (Ionimed VOC standard, Innsbruck, Austria), including isoprene, $\alpha$-pinene, and acetone, amongst others. The calibration was performed for a relative humidity range of 0 to $100 \%$ (steps of $20 \%$ ) at room temperature. However, especially for $\alpha$-pinene (measured at 81 and $137 \mathrm{Th}$ ), the sensitivity of the PTR-MS operating at the rather high $E / N$ was not depending on relative humidity. For isoprene (measured at 41 and $69 \mathrm{Th}$ ), a higher RH led to lower fragmentation inside the instrument, but this did not affect the overall sensitivity much $(<5 \%$ decrease from 20 to $100 \%$ ).

The PTR-MS cannot readily distinguish between different monoterpenes as all have the same molecular weight, so only the sum of monoterpenes could be measured. However, since $\alpha$-pinene is often the most abundant monoterpene in continental midlatitudes (Geron et al., 2000; Janson and de Serves, 2001) and the reaction rate constants for different monoterpenes are rather similar (Tani et al., 2003; Cappellin et al., 2012), our estimation of total monoterpene concentration should not be affected by large errors.

\subsection{Other instrumentation}

Trace gas monitors were used to measure the mixing ratios of sulfur dioxide (model 43i TLE trace level $\mathrm{SO}_{2}$ analyzer, Thermo Scientific), ozone (model 400 ozone monitor, Teledyne API) and nitrogen oxides ( $\mathrm{NO}_{x}$, APNA-360 ambient $\mathrm{NO}_{x}$ monitor, Horiba). These instruments were calibrated once before the campaign with known amounts of trace gases and dry zero air was applied on a daily basis for a duration of at least half an hour in order to take instrument drifts into account. The detection limits of the gas monitors are $0.05 \mathrm{ppbv}$ for the $\mathrm{SO}_{2}$ monitor (for a 5 min integration time), approximately $0.5 \mathrm{ppbv}$ for the $\mathrm{NO}_{x}$ monitor and 0.5 to $1 \mathrm{ppbv}$ for the $\mathrm{O}_{3}$ monitor.

Further instruments used include condensation particle counters (CPCs) and differential mobility analyzers (DMAs). Model 3025A and 3010 CPCs (TSI, Inc.) were used to determine the total particle concentration above their cut-off sizes of 2.5 and $10 \mathrm{~nm}$, respectively. A scanning mobility parti- 


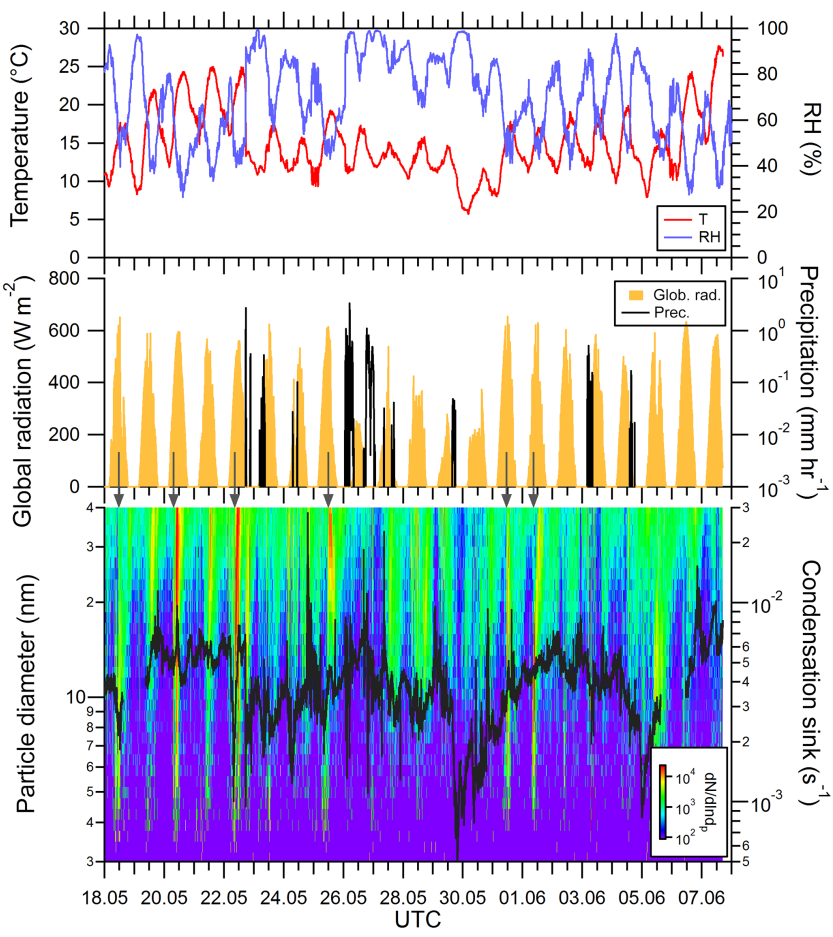

Figure 1. Overview of the different parameters measured between 18 May and 8 June 2014. Temperature $(T)$ and relative humidity (RH) are shown in the upper panel, the center panel shows the global radiation and precipitation, and the bottom panel shows the number size distribution measured by the nano-DMA together with the condensation sink (black line). Gray arrows above the bottom panel indicate days when significant NPF was observed.

cle sizer (SMPS) from TSI (model 3081 long DMA with a model 3776 CPC) determined the particle size distribution between 16 and $600 \mathrm{~nm}$. The smaller size range was covered by a nDMA (Grimm Aerosol Technik, Germany) and a TSI model 3776 CPC for diameters between 3 and $40 \mathrm{~nm}$. The combined size distribution can be used to calculate the condensation/coagulation sink towards certain trace gases (e.g., sulfuric acid) or particle diameters.

Meteorological parameters were both obtained from our own measurements with a Vaisala sonde (model WXT 520), which yielded the temperature, $\mathrm{RH}$, wind speed and direction, and the amount of precipitation. The same parameters are also available for the Vielbrunn meteorological station from the DWD; additionally, values for the global radiation were provided by the DWD.

\section{Results}

\subsection{Meteorological conditions and overview}

The intensive phase of the campaign was from 18 May to 7 June 2014 (21 campaign days). Figure 1 shows an overview

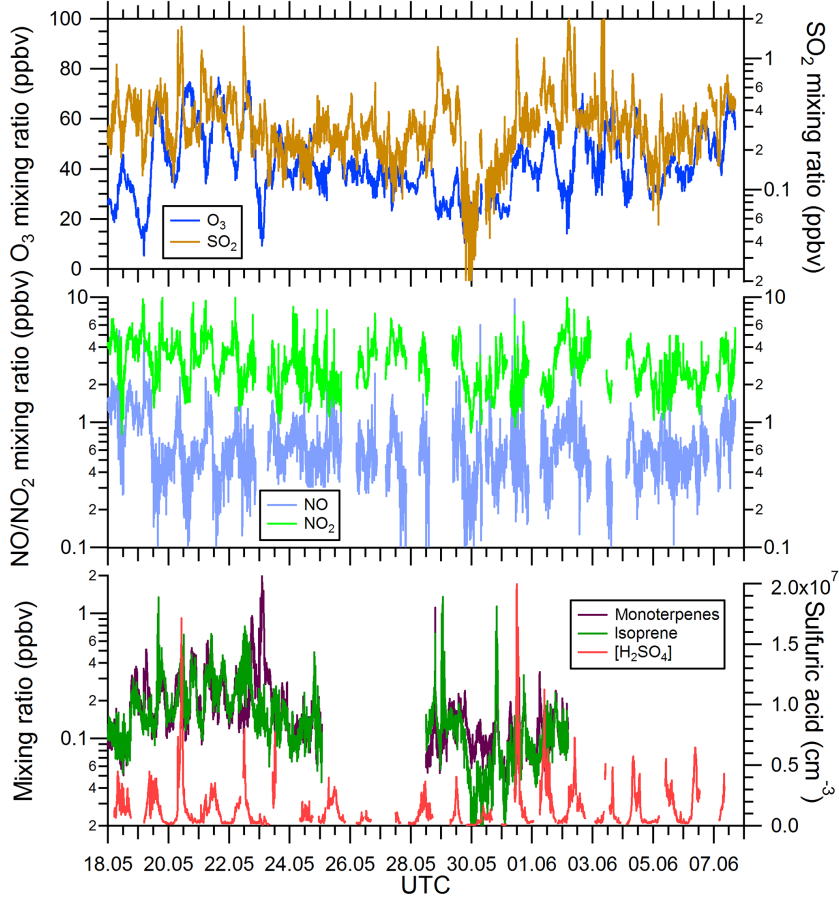

Figure 2. Overview of the trace gas measurements between 18 May and 8 June 2014. The $\mathrm{SO}_{2}$ and $\mathrm{O}_{3}$ mixing ratios are shown in the upper panel, the $\mathrm{NO}$ and $\mathrm{NO}_{2}$ mixing ratios are shown in the center panel, and the bottom panel shows the sulfuric acid monomer concentration $\left(\left[\mathrm{H}_{2} \mathrm{SO}_{4}\right]\right)$ together with the isoprene and monoterpene mixing ratios.

of the meteorological conditions, i.e., temperature, relative humidity, global radiation and precipitation. The size distribution of small particles (Fig. 1, bottom panel) was measured by the nDMA. In addition, the condensation sink calculated for the loss of sulfuric acid on aerosol particles is also shown taking into account the full size distribution (up to $600 \mathrm{~nm}$ ).

The first part of the campaign (including 22 May) was characterized by warm temperatures and sunny weather without precipitation. Between $22 / 23$ and 31 May the weather conditions were less stable with colder temperatures and some precipitation events. Especially on 29 May, a strong drop in temperature and the condensation sink was observed, due to a cold front followed by the passage of relatively clean air. From 31 May onward, temperatures increased again and it was mostly sunny, with only two rain events on 3 and 4 June.

Elevated concentrations of small particles could be observed on almost every day. However, NPF from the smallest sizes (around $3 \mathrm{~nm}$ ) followed by clear growth were seen only on 6 days out of 21 (i.e., 29\%). These events, which were also used for the calculation of NPF rates (Sect. 3.9), are highlighted in the bottom panel of Fig. 1 by the dark-gray arrows. The presence of small particles was also observed on 


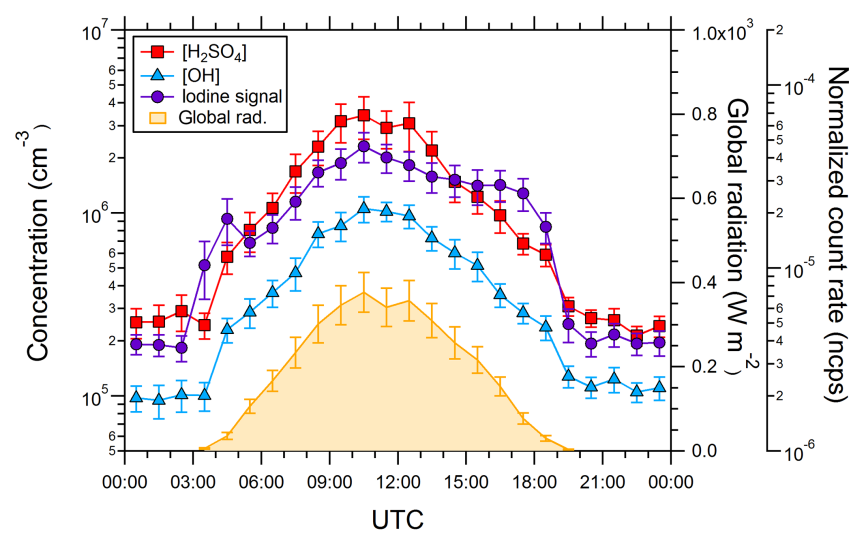

Figure 3. Diurnal averages for the sulfuric acid $\left(\left[\mathrm{H}_{2} \mathrm{SO}_{4}\right]\right)$ and the calculated hydroxyl radical $([\mathrm{OH}])$ concentrations (axis on the left). The iodine signal is not converted into a concentration; instead, the normalized count rates per second (ncps) are shown (axis on the right). A value of $5 \times 10^{-5}$ ncps for iodine would correspond to a concentration of $3 \times 10^{5}$ molecules $\mathrm{cm}^{-3}$ when applying the same conversion factor for iodic acid as for sulfuric acid. The global radiation indicates that all signals are related to photochemistry. Error bars indicate 1 standard deviation for the $30 \mathrm{~min}$ averaged values.

several other days; however, the events were either relatively weak or no clear particle growth was observable.

\subsection{Trace gas measurements}

The trace gas measurements are shown in Fig. 2. Typical maximum daytime ozone mixing ratios ranged from $\sim 40$ to 75 ppbv (Fig. 2, upper panel). The sulfur dioxide levels were between 0.05 and a maximum of $2 \mathrm{ppbv}$, with average values around $0.3 \mathrm{ppbv}$ (Fig. 2, upper panel). Especially during the passage of clean air on 29 and 30 May, the $\mathrm{SO}_{2}$ levels were quite low. $\mathrm{NO}_{2}$ mixing ratios showed a distinct diurnal pattern with a minimum in the late afternoon and an average mixing ratio around $3 \mathrm{ppbv}$ (Fig. 2, middle panel; see also Fig. 8). The NO mixing ratios were about a factor of 5 lower compared to $\mathrm{NO}_{2}$ on average (Fig. 2, middle panel; see also Fig. 8); similar values were reported for another rural site in Germany (Mutzel et al., 2015). The maximum sulfuric acid concentrations were reached around noon and ranged between $\sim 1 \times 10^{6}$ and $2 \times 10^{7}$ molecules $\mathrm{cm}^{-3}$ (Fig. 2, lower panel; see also Fig. 3), which is comparable to other sites (Fiedler et al., 2005; Petäjä et al., 2009). The total monoterpene and isoprene mixing ratios measured by the PTR-MS were similar to each other with values between $\sim 0.03$ and 1 ppbv (Fig. 2, lower panel). Mixing ratios in the same range have also been reported for the boreal forest (Rantala et al., 2014).

\section{3 $\mathrm{H}_{2} \mathrm{SO}_{4}$ measurement and calculation from proxies}

Figure 3 shows the average diurnal sulfuric acid concentration along with other data, which will be discussed in later sections. The maximum average $\left[\mathrm{H}_{2} \mathrm{SO}_{4}\right]$ around noon was $\sim 3 \times 10^{6}$ molecules $\mathrm{cm}^{-3}$; the error bars represent 1 standard deviation.

Recently, Mikkonen et al. (2011) introduced approximations to calculate sulfuric acid as a function of different proxies. Since the relevant parameters (sulfur dioxide mixing ratio, global radiation, relative humidity and condensation sink) are available, we have used the following formula to approximate the sulfuric acid concentration (Mikkonen et al., 2011):

$\left[\mathrm{H}_{2} \mathrm{SO}_{4}\right]_{\text {proxy }}=a \cdot k(T, p) \cdot\left[\mathrm{SO}_{2}\right]^{b} \cdot \mathrm{Rad}^{c} \cdot \mathrm{RH}^{d} \cdot \mathrm{CS}^{e}$.

The $\left[\mathrm{H}_{2} \mathrm{SO}_{4}\right]$ (expressed in molecules $\mathrm{cm}^{-3}$ ) is calculated as a function of the $\mathrm{SO}_{2}$ mixing ratio (in ppbv), the global radiation $\mathrm{Rad}$ (in $\mathrm{W} \mathrm{m}^{-2}$ ), the relative humidity $\mathrm{RH}$ (in $\%$ ), the condensation sink CS (in $\mathrm{s}^{-1}$ ), a rate constant $k$, which depends on ambient pressure $p$ and temperature $T$ (see definition for $k$ by Mikkonen et al., 2011) and a scaling factor $a$. A least-squares fit made with the software IGOR yields the coefficients $a=1.321 \times 10^{15}, b=0.913$, $c=0.990, d=-0.217$ and $e=-0.526$ (linear correlation coefficient, Pearson's $r$, is 0.87 ). Following the recommendations given by Mikkonen et al. (2011) we restricted the data used in the derivation of the parameters to conditions where the global radiation was equal or larger than $50 \mathrm{~W} \mathrm{~m}^{-2}$. In addition, a simpler formulation was also tested, which neglects the dependence on RH and CS:

$\left[\mathrm{H}_{2} \mathrm{SO}_{4}\right]_{\text {proxy }}=a^{\prime} \cdot k(T, p) \cdot\left[\mathrm{SO}_{2}\right]^{b^{\prime}} \cdot \operatorname{Rad}^{c^{\prime}}$.

Here, the coefficients $a^{\prime}=1.343 \times 10^{16}, b^{\prime}=0.786$ and $c^{\prime}=0.941$ yield good agreement (linear correlation coefficient, Pearson's $r$, is 0.85 ) between calculated and measured $\left[\mathrm{H}_{2} \mathrm{SO}_{4}\right]$. Figure 4 shows a comparison between the two approximation methods and the measured sulfuric acid for the full campaign (when $\mathrm{Rad} \geq 50 \mathrm{~W} \mathrm{~m}^{-2}$ ). In almost all cases the predicted $5 \mathrm{~min}$ averages are within a factor of 3 of the measured values for both methods. This indicates that even the simpler method (Eq. 3) can yield relatively accurate results for the conditions of this study. This is probably due to the fact that RH and CS show only relatively small variations over the duration of the campaign and it would therefore not be absolutely necessary to include these factors in the sulfuric acid calculation. Nevertheless, whenever the data are available, we recommend using the more detailed parameterization (Eq. 2) as it treats the sulfuric acid concentration calculation more rigorously. The parameters found are in good agreement with the ones reported by Mikkonen et al. (2011) for different sites.

\subsection{Calculated OH}

For further data evaluation, knowledge of the $\mathrm{OH}$ concentrations is useful. In this study the hydroxyl radical concentration is required to derive an estimated concentration of the 


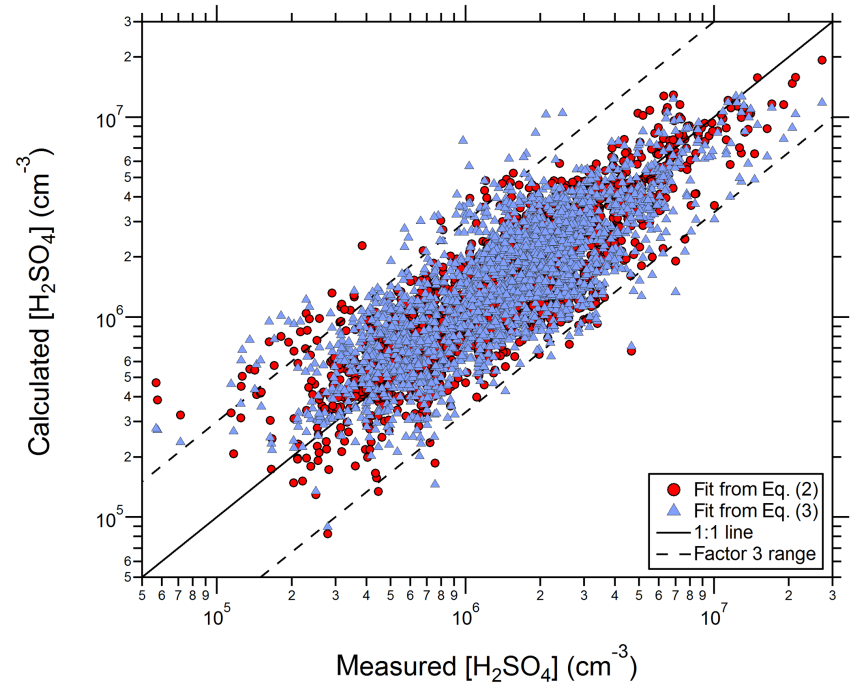

Figure 4. Calculated $\left[\mathrm{H}_{2} \mathrm{SO}_{4}\right]$ as a function of the measured concentrations. Only data points where the global radiation exceeded $50 \mathrm{~W} \mathrm{~m}^{-2}$ were considered in deriving the fit parameters for Eqs. (2) and (3). The red circles take into account $\mathrm{SO}_{2}$, global radiation ( $\mathrm{Rad})$, condensation sink (CS) and relative humidity $(\mathrm{RH})$ to calculate the $\left[\mathrm{H}_{2} \mathrm{SO}_{4}\right]$, whereas only $\mathrm{SO}_{2}$ and global radiation are used for the blue triangles.

iodine species OIO (Sect. 3.5) and for a comparison of conditions during nucleation and no-nucleation days (Sect. 4). Since there was no direct measurement of the hydroxyl radical available, only an estimation based on other measured parameters can be made. This estimation is based on the assumption that most of the sulfuric acid is produced from the reaction between $\mathrm{SO}_{2}$ and $\mathrm{OH}$. Using the condensation sink CS the balance equation between production and loss at steady state can be used to derive the $\mathrm{OH}$ :

$$
\begin{aligned}
{[\mathrm{OH}] } & =\frac{\mathrm{CS} \cdot\left[\mathrm{H}_{2} \mathrm{SO}_{4}\right]-k_{X+\mathrm{SO}_{2}} \cdot[\mathrm{X}] \cdot\left[\mathrm{SO}_{2}\right]}{k_{\mathrm{OH}+\mathrm{SO}_{2}} \cdot\left[\mathrm{SO}_{2}\right]} \\
& \approx \frac{\mathrm{CS} \cdot\left[\mathrm{H}_{2} \mathrm{SO}_{4}\right]}{k_{\mathrm{OH}+\mathrm{SO}_{2} \cdot\left[\mathrm{SO}_{2}\right]}} .
\end{aligned}
$$

Recently, it was discovered that there are also other species capable of oxidizing $\mathrm{SO}_{2}$ to $\mathrm{SO}_{3}$ (which lead to subsequent production of $\mathrm{H}_{2} \mathrm{SO}_{4}$ due to further reactions with $\mathrm{O}_{2}$ and $\mathrm{H}_{2} \mathrm{O}$; Mauldin et al., 2012). Those species $X$, e.g., stabilized Criegee intermediates (sCI), can be formed via the ozonolysis of alkenes (e.g., isoprene, $\alpha$-pinene, limonene; Mauldin et al., 2012; Berndt et al., 2014). Therefore, if some $\mathrm{H}_{2} \mathrm{SO}_{4}$ is generated from sCI reactions with $\mathrm{SO}_{2}$, then the calculated $\mathrm{OH}$ is an upper estimate. During the day this effect should be relatively small, i.e., $<50 \%$ (Boy et al., 2013; Sarwar et al., 2013), although Berndt et al. (2014) state that no final answer can be given regarding the effect of the sCI on the sulfuric acid formation because it depends strongly on the sCI structure and competitive reactions between sCI and water vapor. However, it should also be noted that the reaction between alkenes and ozone generates not only sCI but also $\mathrm{OH}$ at significant yields (e.g., the $\mathrm{OH}$ yield for the reaction of $\alpha$-pinene and $\mathrm{O}_{3}$ is ca. 0.77; Forester and Wells, 2011) and that the $\mathrm{OH}$ produced via this mechanism is taken into account by Eq. (4). Data from Sipilä et al. (2014) further suggest that the production of sulfuric acid from $\mathrm{SCI}$ oxidation of $\mathrm{SO}_{2}$ is probably minor compared to that from $\mathrm{OH}$ and $\mathrm{SO}_{2}$. For these reasons we have decided to calculate the $[\mathrm{OH}]$ not only for the daytime but for the full day. The derived diurnal pattern of $[\mathrm{OH}]$ is shown in Fig. 3 with a maximum concentration of $1 \times 10^{6}$ molecules $\mathrm{cm}^{-3}$ around noon, which is in good agreement with other studies where $\mathrm{OH}$ was measured directly (Berresheim et al., 2000; Rohrer and Berresheim, 2006; Petäjä et al., 2009).

\subsection{Iodic acid $\left(\mathrm{HIO}_{3}\right)$ and $\mathrm{OIO}$}

The high-resolution CI-APi-TOF mass spectra revealed the presence of iodine containing substances. It can be ruled out that these signals result from instrument contamination as our CI-APi-TOF had never been in contact with iodine (i.e., no nucleation experiments with iodine have yet been performed and no iodide primary ions have been used). The observed signals could be assigned to $\mathrm{IO}_{3}^{-},\left(\mathrm{H}_{2} \mathrm{O}\right) \mathrm{IO}_{3}^{-}$and $\left(\mathrm{HNO}_{3}\right) \mathrm{IO}_{3}^{-}$(Table 1). To our knowledge the identification of iodine-related peaks has not been reported from measurements with a nitrate chemical ionization mass spectrometer (CIMS). However, Berresheim et al. (2000) reported the presence of a peak at $m / z 175$ in the spectrum for the marine environment, which was not identified previously but, in the light of this study, can almost certainly be attributed to $\mathrm{IO}_{3}^{-}$.

The diurnal pattern of $\mathrm{IO}_{3}^{-}$and the related iodine peaks show a distinct pattern with a maximum around noon following the diurnal pattern of sulfuric acid almost perfectly (Fig. 3). This may not be surprising since the formation of $\mathrm{HIO}_{3}$ is due to reaction between OIO and OH (Saiz-Lopez et al., 2012); therefore, the iodic acid concentration is connected to the $\mathrm{OH}$ chemistry. After normalization of the iodic acid signals with the nitrate primary ion count rates, a concentration of the neutral compound $\mathrm{HIO}_{3}$ can be obtained by tentatively adopting the same calibration constant for iodic acid as for sulfuric acid. Thereby a maximum average daytime concentration of $\sim 3 \times 10^{5}$ molecules $\mathrm{cm}^{-3}$ can be found. Further, using the derived $\mathrm{OH}$ concentrations from the $\mathrm{H}_{2} \mathrm{SO}_{4}$ and CS measurements (Sect. 3.4), the derived [ $\left.\mathrm{HIO}_{3}\right]$ can be used to estimate the concentration of OIO (Saiz-Lopez et al., 2012):

$[\mathrm{OIO}]=\frac{\mathrm{CS} \cdot\left[\mathrm{HIO}_{3}\right]}{k_{\mathrm{OH}+\mathrm{OIO} \cdot[\mathrm{OH}]} .}$

Equation (5) assumes that the only production channel of $\mathrm{HIO}_{3}$ is the reaction between $\mathrm{OH}$ and $\mathrm{OIO}$ and the only loss mechanism of $\mathrm{HIO}_{3}$ is the uptake on aerosol. The reaction rate $k_{\mathrm{OH}+\mathrm{OIO}}$ can be taken from the literature (Plane et al., 2006). In this way the concentration of OIO can be estimated 
to a typical value of $5 \times 10^{6}$ molecules $\mathrm{cm}^{-3}$, which is much lower than the values reported for the marine environment ( 3 to 27 pptv, i.e., $7.5 \times 10^{7}$ to $6.8 \times 10^{8}$ molecules $\mathrm{cm}^{-3}$; see Saiz-Lopez et al., 2012).

The relatively low values of $\left[\mathrm{HIO}_{3}\right]$ and $[\mathrm{OIO}]$ probably indicate that iodine chemistry is not very important in terms of NPF at this site. This is supported by the fact that we could not observe any clusters containing, for example, sulfuric acid and iodic acid or clusters containing more than one iodine molecule. However, it is surprising that iodine can be detected more than $400 \mathrm{~km}$ away from the nearest coast line. On the other hand, HYSPLIT back-trajectory calculations (Stein et al., 2015) reveal that in most cases the air was arriving from westerly directions and therefore had contact with the ocean within the last $48 \mathrm{~h}$ before arriving at the station. During the measurement period there was unfortunately never a day where the air was clearly coming from easterly directions and had not been in contact with the Atlantic Ocean or Mediterranean Sea within the previous days. Therefore, we could not check whether this would result in lower iodine signals. Despite the marine origin of the air masses observed, it is not clear how the iodine is transported over relatively large distances without being lost on aerosol particles. If iodic acid is irreversibly lost on aerosol (similar to sulfuric acid) its lifetime should only be on the order of several minutes at typical boundary layer conditions. Therefore, the presence of iodine indicates either a local iodine source or its transport from marine environments in the form of a reservoir substance, e.g., $\mathrm{CH}_{3} \mathrm{I}$ (the lifetime of $\mathrm{CH}_{3} \mathrm{I}$ is in the order of 1 week; see Saiz-Lopez et al., 2015), and subsequent release due to photolysis.

Regarding the sensitivity of the CI-APi-TOF it can be said that iodic acid (and, if present, probably also its clusters) can be detected with high sensitivity. One aspect that helps in unambiguously identifying iodic acid is the high negative mass defect of the iodine atom $(\Delta m \approx-0.1 \mathrm{Th})$. Furthermore, this also contributes to the low detection limit for this compound because generally there will not be any overlapping signals from other substances with the same integer mass (mass resolving power of the instrument is $\sim 4000 \mathrm{Th} / \mathrm{Th}-$ i.e., at $\mathrm{m} / z 175$ the peak width at half maximum is $\sim 0.04 \mathrm{Th}$ ). The method introduced here therefore allows high-sensitivity measurement of $\left[\mathrm{HIO}_{3}\right]$ as well as the estimation of [OIO] with the help of Eq. (5) in future studies. The lowest detectable concentrations should be around $3 \times 10^{4}$ molecules $\mathrm{cm}^{-3}$, or better, for $\left[\mathrm{HIO}_{3}\right]$ and $5 \times 10^{5}$ molecules $\mathrm{cm}^{-3}$ (ca. $0.02 \mathrm{pptv}$ ) for [OIO] when assuming the same calibration constant for $\mathrm{HIO}_{3}$ as for $\mathrm{H}_{2} \mathrm{SO}_{4}$ and considering the lowest iodine signal from Fig. 3.

\subsection{Amine, nitrosamine and ammonia measurements}

The detection of dimethylamine (DMA, $\left.\left(\mathrm{CH}_{3}\right)_{2} \mathrm{NH}\right)$ by means of nitrate chemical ionization with a CI-APi-TOF has been described previously (Simon et al., 2016). The clus- tering between diethylamine (DEA) and nitrate ion clusters has also been reported by Luts et al. (2011). The amines detected in the present study include $\mathrm{CH}_{5} \mathrm{~N}$ (monomethylamine), $\mathrm{C}_{2} \mathrm{H}_{7} \mathrm{~N}$ (dimethylamine, DMA, or ethylamine, EA), $\mathrm{C}_{3} \mathrm{H}_{9} \mathrm{~N}$ (trimethylamine, TMA, or propylamine, $\mathrm{PA}$ ), $\mathrm{C}_{4} \mathrm{H}_{11} \mathrm{~N}$ (diethylamine, DEA) and $\mathrm{C}_{6} \mathrm{H}_{15} \mathrm{~N}$ (triethylamine, TEA). All of these amines are identified as clusters in the CI-APi-TOF spectra where the amines are associated with both the nitrate dimer $\left((\right.$ amine $\left.)\left(\mathrm{HNO}_{3}\right) \mathrm{NO}_{3}^{-}\right)$and the trimer ((amine) $\left.\left(\mathrm{HNO}_{3}\right)_{2} \mathrm{NO}_{3}^{-}\right)$.

The high mass resolving power of the CI-APi-TOF allowed the identification of five different amines $\left(\mathrm{C}_{1}, \mathrm{C}_{2}, \mathrm{C}_{3}\right.$, $\mathrm{C}_{4}$ and $\mathrm{C}_{6}$ amines; see above). Since the amines are all identified at two different masses each (with either the nitrate dimer or the nitrate trimer), plotting the time series of each pair of signals allows further verification of the amine signals since a different time trend would reveal that another ion would interfere with the amine signal. This was sometimes the case when the relative humidity was high and clusters of water and nitrate appeared with high water numbers. The cluster of $\mathrm{NO}_{3}^{-}$and 6 water molecules has a mass of 170.0518 Th and the $\mathrm{C}_{2}$ amine cluster $\left(\mathrm{C}_{2} \mathrm{H}_{7} \mathrm{~N}\right)\left(\mathrm{HNO}_{3}\right) \mathrm{NO}_{3}^{-}$ $(170.0419 \mathrm{Th})$ cannot be separated from this primary ion cluster. Therefore, if large nitrate plus water clusters were observed in the spectra, no $\mathrm{C}_{2}$ amine signal could be evaluated.

The same ion cluster chemistry applies for ammonia, which can also bind with the nitrate cluster ions. Consequently, ammonia is detected as $\left(\mathrm{NH}_{3}\right)\left(\mathrm{HNO}_{3}\right) \mathrm{NO}_{3}^{-}$and $\left(\mathrm{NH}_{3}\right)\left(\mathrm{HNO}_{3}\right)_{2} \mathrm{NO}_{3}^{-}$(Table 1). To our knowledge the existence of these cluster ions has not been reported previously.

In accordance with Simon et al. (2016), the cluster ion signals have been normalized by the following relationship:

amine $_{n c p s}=\ln \left(1+\frac{\left\{(\text { amine })\left(\mathrm{HNO}_{3}\right) \mathrm{NO}_{3}^{-}\right\}+\left\{(\text {amine })\left(\mathrm{HNO}_{3}\right)_{2} \mathrm{NO}_{3}^{-}\right\}}{\left\{\left(\mathrm{HNO}_{3}\right)_{2} \mathrm{NO}_{3}^{-}\right\}}\right)$,

where the curly brackets denote the count rates of the different ion clusters and the same formula can be used when "amine" is replaced by $\mathrm{NH}_{3}$ to obtain the normalized ammonia signal. The normalization with the nitrate trimer has been chosen because we think that this is the dominant nitrate ion cluster the amines (and ammonia) can bind to within the CIAPi-TOF ion reaction zone (Simon et al., 2016). Partial evaporation of one $\mathrm{HNO}_{3}$ from the resulting amine nitrate cluster within the CI-APi-TOF vacuum chamber leads to the spread of the signal over the related masses separated by $62.9956 \mathrm{Th}$ $\left(\mathrm{HNO}_{3}\right)$.

In addition to the five amines mentioned before, we were able to identify dimethylnitrosamine (NDMA, $\left.\left(\mathrm{CH}_{3}\right)_{2} \mathrm{NNO}\right)$ from its clusters $\left(\left(\mathrm{CH}_{3}\right)_{2} \mathrm{NNO}\right)\left(\mathrm{HNO}_{3}\right) \mathrm{NO}_{3}^{-}$ and $\left(\left(\mathrm{CH}_{3}\right)_{2} \mathrm{NNO}\right)\left(\mathrm{HNO}_{3}\right)_{2} \mathrm{NO}_{3}^{-}$(Table 1). The signals from NDMA show a clear diurnal pattern on some days, which can be up to about 2 orders of magnitude higher during the night compared to the day. This is in agreement with the formation mechanism of NDMA via the reaction of DMA 

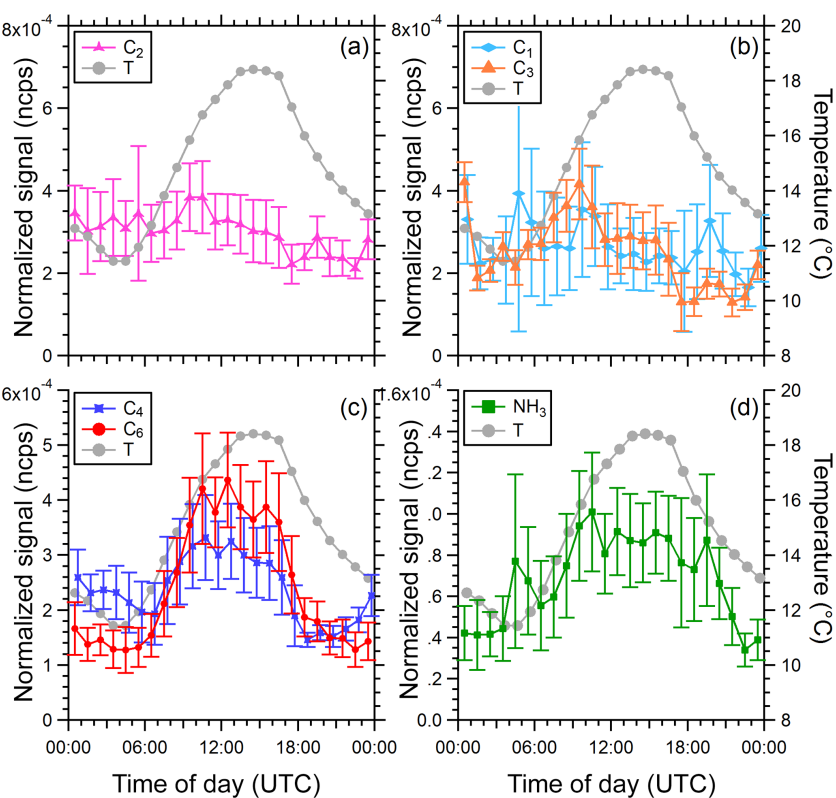

Figure 5. Diurnal averages for different amines $\left(\mathrm{C}_{1}, \mathrm{C}_{2}, \mathrm{C}_{3}, \mathrm{C}_{4}\right.$ and $\mathrm{C}_{6}$ ) and ammonia. The temperature profile is shown in addition. Error bars represent 1 standard deviation of the $30 \mathrm{~min}$ averages. The lower detection limits for the different compounds are not well defined. However, the lowest measured signals during some periods were $0.3 \times 10^{-4}$ ncps for $\mathrm{C}_{1} ; \sim 0.5 \times 10^{-4}$ ncps for $\mathrm{C}_{2}, \mathrm{C}_{3}, \mathrm{C}_{4}$ and $\mathrm{C}_{6}$; and $0.1 \times 10^{-4}$ ncps for ammonia. For most of the time (and for all averaged values shown) the signals were clearly above these "background" levels.

with $\mathrm{OH}$ and NO (Nielsen et al., 2012). The lower concentrations during the day can be explained by the rapid photolysis rate of NDMA (Nielsen et al., 2012). Since only $\mathrm{C}_{2}$ amines are capable of forming nitrosamines, no further nitrosamine could be identified from the mass spectra. Only a rough estimation of the mixing ratio can be provided by using the calibration constant from Simon et al. (2016) which was derived for DMA. Using this calibration constant the maximum mixing ratio of NDMA would be $\sim 100 \mathrm{pptv}$ (or $2.5 \times 10^{9}$ molecules $\mathrm{cm}^{-3}$ ). However, this value has a high uncertainty because no direct calibration with NDMA was performed.

The average diurnal patterns of the four amines and ammonia are shown in Fig. 5. The data are an average over 21 measurement days and the error bars represent 1 standard deviation. The temperature profile is shown along with the CI-APi-TOF signals. The $\mathrm{C}_{4}$ and $\mathrm{C}_{6}$ amines and ammonia show a distinct diurnal profile which follows the temperature profile closely. The temperature-dependent signal intensity could be due to partial re-evaporation of amines from the particulate phase. No correlation with temperature is seen for the $\mathrm{C}_{1}, \mathrm{C}_{2}$ and $\mathrm{C}_{3}$ amines, which could indicate efficient stabilization of these amines in the particulate phase due to acidbase reactions (Kirkby et al., 2011; Almeida et al., 2013).
No direct calibration for amines, NDMA and ammonia was performed during the campaign. Therefore, only a rough estimation of the mixing ratios can be made. Using the calibration curve for DMA by Simon et al. (2016), $1 \times 10^{-4} \mathrm{ncps}$ (normalized counts per second) corresponds to $\sim 1 \mathrm{pptv}$ of DMA. With this conversion the average mixing ratios are between about 1 and 5 pptv for the amines. The mixing ratios from this study are in a similar range to those reported from measurements in a southeastern US forest (You et al., 2014) but generally lower than those from three different sites in the USA (Freshour et al., 2014).

The ncps for ammonia are lower than for the amines, which should not be the case if the sensitivity towards ammonia and amines were the same because the ammonia mixing ratios are almost certainly higher than the ones for the amines in this environment. The ammonia mixing ratio can be above several ppbv in rural areas (von Bobrutzki et al., 2010). Therefore, the sensitivity of the nitrate CI-APi-TOF towards ammonia seems to be significantly lower than for amines. This is reasonable since other studies have found that acid-base clusters between sulfuric acid (including the bisulfate ion) and amines are much more stable compared to sulfuric acid ammonia clusters (Kirkby et al., 2011; Almeida et al., 2013). Therefore, the acid-base clustering between nitric acid (including the nitrate ion) and ammonia or amines could follow a similar rule, which would lead to faster evaporation of the ammonia nitrate clusters. For this reason, only the relative signals for ammonia can be used at the moment without providing estimated mixing ratios.

Recently, it was suggested that diamines could play an important role in ambient NPF (Jen et al., 2016a); however, we could not identify diamines from the high-resolution mass spectra.

\subsection{Sulfuric acid dimer}

Occasionally, the CI-APi-TOF sulfuric acid dimer signal was above background levels. The dimer $\left(\left(\mathrm{H}_{2} \mathrm{SO}_{4}\right) \mathrm{HSO}_{4}^{-}\right)$was identified from the high-resolution spectra on nine campaign days. The measured sulfuric acid dimer concentrations are shown as a function of the sulfuric acid monomer concentrations in Fig. 6. For comparison, CLOUD chamber data from nucleation experiments in the ternary sulfuric acid-waterdimethylamine system are included (red circles in Fig. 6; Kürten et al., 2014). In addition, the lower dashed line shows the expected dimer formation due to ion-induced clustering (IIC) of sulfuric acid monomers in the CI-APi-TOF ion reaction zone (Hanson and Eisele, 2002; Zhao et al., 2010).

The data indicate that the measured dimer concentrations are clearly above the background level set by ion-induced clustering. On the other hand, the concentrations are lower than what has been measured in CLOUD for kinetic nucleation in the sulfuric acid-water-dimethylamine system at $5^{\circ} \mathrm{C}$ and $38 \%$ RH (Almeida et al., 2013; Kürten et al., 2014). Clearly, the neutral sulfuric acid dimers were stabilized by a 


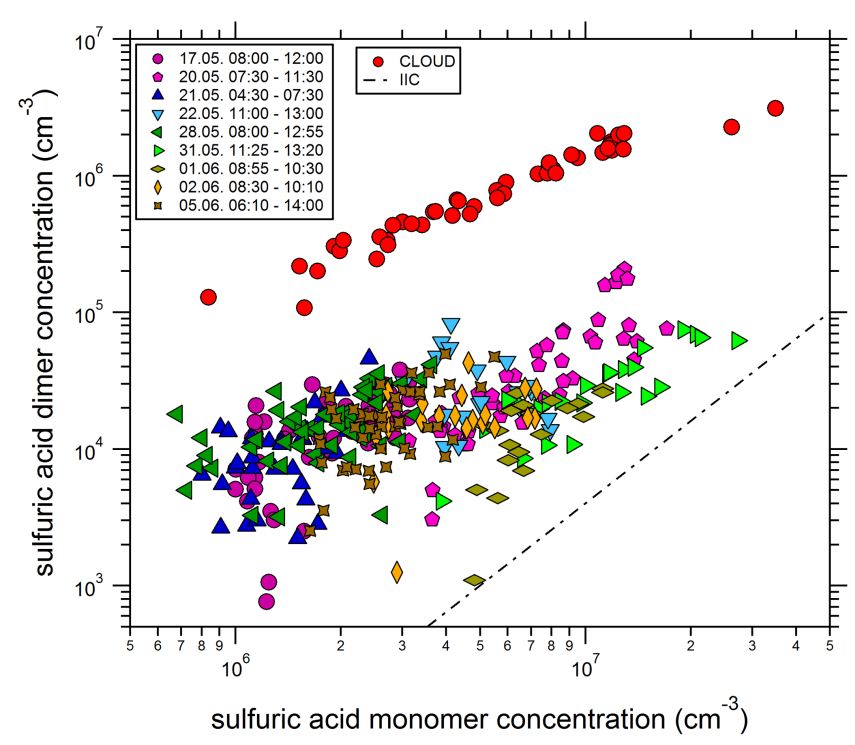

Figure 6. Sulfuric acid dimer concentrations as a function of the sulfuric acid monomer concentrations. The legend on the left lists the periods when high dimer signals were observed. In addition, data from CLOUD chamber experiments with at least $10 \mathrm{pptv}$ of dimethylamine are shown; under these conditions dimer formation proceeds at or close to the kinetic limit (Kürten et al., 2014). The dashed-dotted line indicates the lower detection limit for neutral dimers set by ion-induced clustering (IIC) within the CI-APi-TOF ion reaction zone.

ternary compound, as otherwise their concentrations would not have been measurable at these relatively warm conditions because the dimer (without a ternary compound) evaporation rate is quite high $\left(>10^{5} \mathrm{~s}^{-1}\right.$ at $290 \mathrm{~K}$; Hanson and Lovejoy, 2006; Kürten et al., 2015). On the other hand, the ternary stabilizing agent evaporates after charging of the sulfuric acid dimers because no cluster between the sulfuric acid dimer and another compound (besides $\mathrm{HNO}_{3}$ from the ion source) could be identified. This means that although the dimers contained at least one additional molecule in the neutral state, the ionized dimer will be detected as $\left(\mathrm{H}_{2} \mathrm{SO}_{4}\right) \mathrm{HSO}_{4}^{-}$(Ortega et al., 2014; Jen et al., 2014), which makes it impossible to identify the stabilizing agent. Only when larger clusters of sulfuric acid are present (trimer and larger) can stabilizing agents like ammonia or amines stay in the cluster after charging with the nitrate ion (Zhao et al., 2011; Kirkby et al., 2011; Ortega et al., 2014; Kürten et al., 2014). Unfortunately, no large sulfuric acid clusters (trimer and larger) were measurable during the campaign, probably because their concentrations were too low. Therefore, only speculations about the stabilizing agent responsible for the high dimer concentrations can be made. It is quite unlikely that ammonia would be the only stabilizing compound for the dimers since previous studies have shown that the relatively high dimer concentration measured at rather low sulfuric acid monomer concentrations $\left(<2 \times 10^{7}\right.$ molecules $\left.\mathrm{cm}^{-3}\right)$ cannot be explained by sulfuric acid-ammonia-water nucleation (Hanson and Eisele, 2002; Jen et al., 2014). In addition, efficient clustering between sulfuric acid and iodic acid can probably be ruled out (provided that these compounds would be capable of producing a cluster with a low evaporation rate) as the concentrations of iodic acid are quite low $\left(\sim 3 \times 10^{5}\right.$ molecules $\mathrm{cm}^{-3}$ at maximum; see Sect. 5). This means that the arrival rate of iodic acid on a sulfuric acid dimer is on the order of $10^{-4} \mathrm{~s}^{-1}$ (using a collision rate of $5 \times 10^{-10} \mathrm{~cm}^{3}$ molecules ${ }^{-1} \mathrm{~s}^{-1}$ ). Due to the high evaporation rate of the pure sulfuric acid dimer, no significant dimer stabilization by iodic acid can be expected.

Whether amines are responsible for the dimer formation in the present study cannot be concluded. If they were, the lower dimer concentrations compared to the CLOUD chamber results (Kürten et al., 2014) could be attributed to the higher temperatures in the present study, which result in faster evaporation rates. Another explanation would be the lower amine mixing ratios. In the CLOUD study, dimethylamine was present at $10 \mathrm{pptv}$ or higher. In addition, it cannot be concluded that, for example, the measured $\mathrm{C}_{2}$ amines are all dimethylamine; if a significant fraction of them were, for example, ethylamine, its stabilizing effect could be significantly lower. This remains somewhat speculative as no data regarding NPF from ethylamine and sulfuric acid were found; however, triethylamine was reported to have a relatively weak effect on nucleation compared to DMA or TMA (Glasoe et al., 2015). Other compounds which are present and have been shown to form new particles are HOMs (Schobesberger et al., 2013; Ehn et al., 2014; Riccobono et al., 2014), although their stabilizing effect on neutral sulfuric acid dimers remains to be elucidated.

Regarding the observations shown in Fig. 6, it should be noted that no ion filter (high-voltage electric field in the CI-APi-TOF inlet to remove ambient ions) was used in the present study. This could in principle lead to the detection of ambient ions and clusters, which did not undergo charging in the CI-APi-TOF ion reaction zone. If this were the case, no representative concentrations of the corresponding neutral sulfuric acid dimer would be derived. CLOUD studies reported that charged sulfuric acid monomers $\left(\mathrm{HSO}_{4}^{-}\right)$ and dimers $\left(\left(\mathrm{H}_{2} \mathrm{SO}_{4}\right) \mathrm{HSO}_{4}^{-}\right)$could be observed with a different nitrate CIMS under some conditions (Rondo et al., 2014; Kürten et al., 2015). However, for ambient measurements, no significant effect could be observed for sulfuric acid monomers (Rondo et al., 2014). In principle, the sulfuric acid dimer could be more strongly affected by the detection of ambient ions since the neutral dimer concentration is much lower than the sulfuric acid monomer, while the negative ambient ion spectrum can be dominated by the charged sulfuric acid dimer (Eisele et al., 2006). Therefore, we cannot entirely rule out that ambient ions had some effect on the data shown in Fig. 6. However, the ambient ions would need to overcome an electric field before they could enter the ion reaction zone (Kürten et al., 2011; Rondo et al., 
2014). In the CIMS and the CI-APi-TOF a negative voltage is used to focus the primary ions to the center of the reaction zone, while the sample line is electrically grounded. This means negative ambient ions would need to overcome a repulsing electric field which acts as a barrier. Light ions will be efficiently deflected due to their high mobility, but heavier ions can in principle penetrate more easily. Consequently, CIMS measurements at the CLOUD chamber showed that the apparent dimer signal measured by the CIMS correlated with large ion clusters (pentamer, i.e., $\left(\mathrm{H}_{2} \mathrm{SO}_{4}\right)_{4} \mathrm{HSO}_{4}^{-}$, and larger, which underwent subsequent fragmentation) but not with the $\left(\mathrm{H}_{2} \mathrm{SO}_{4}\right) \mathrm{HSO}_{4}^{-}$signal; the charged clusters were measured simultaneously with an APi-TOF (Junninen et al., 2010; Kürten et al., 2015). The CI-APi-TOF used in this study utilized a higher voltage for the ion focusing compared to the CIMS (ca. $-500 \mathrm{~V}$ instead of $-220 \mathrm{~V}$ in the CIMS) and should therefore prevent smaller masses even more efficiently from entering the ion source than in the study by Kürten et al. (2015). In addition, the absence of any trimer signal $\left(\left(\mathrm{H}_{2} \mathrm{SO}_{4}\right)_{2} \mathrm{HSO}_{4}^{-}\right)$in the spectra argues against ambient ion detection. In a previous study by Eisele et al. (2006) ambient ion measurements also showed, besides signals for $\left(\mathrm{H}_{2} \mathrm{SO}_{4}\right) \mathrm{HSO}_{4}^{-}$, signals for $\left(\mathrm{H}_{2} \mathrm{SO}_{4}\right)_{2} \mathrm{HSO}_{4}^{-}$which were on average $\sim 50 \%$ of the dimer signals. Since the CI-APi-TOF design, with its repulsing voltages towards ambient ions in the ion reaction zone, should be more sensitive towards the trimer than towards the dimer, the absence of sulfuric acid trimer signals argues against a significant bias in the data due to charged ambient clusters.

\subsection{Highly oxidized organic molecules (HOMs)}

Recently, the rapid autoxidation of atmospherically relevant organic molecules, such as isoprene and monoterpenes, was described (Crounse et al., 2013; Ehn et al., 2014). There is evidence that these HOMs are involved in the formation of secondary aerosol and can even promote the formation of new aerosol particles (Jokinen et al., 2015; Kirkby et al., 2016). Nitrate chemical ionization mass spectrometry is capable of detecting a suite of $\mathrm{HOMs}$ when the $\mathrm{O}: \mathrm{C}$ ratio is high (e.g., $>\sim 0.6$ for $\mathrm{C}_{10}$ and $>\sim 0.35$ for $\mathrm{C}_{19} / \mathrm{C}_{20}$ compounds) through association of an $\mathrm{NO}_{3}^{-}$primary ion (Ehn et al., 2014), while other ionization techniques are more selective towards less oxidized compounds (Aljawhary et al., 2013). Many recent publications report peak lists for different compounds identified from chamber or ambient measurements with nitrate chemical ionization (Ehn et al., 2012, 2014; Kulmala et al., 2013; Mutzel et al., 2015; Praplan et al., 2015; Jokinen et al., 2015; Kirkby et al., 2016). The species from the previous studies are mainly $\mathrm{C}_{10}$ (containing 10 carbon atoms) or $\mathrm{C}_{20}$ (containing 19 or 20 carbon atoms) compounds originating from reactions between monoterpenes (in most cases from $\alpha$-pinene) and ozone and/or $\mathrm{OH}$.

The $\mathrm{C}_{10}$ compounds can be further segregated into HOM radicals $\left(\mathrm{RO}_{2}\right.$, i.e., $\left.\mathrm{C}_{10} \mathrm{H}_{15} \mathrm{O}_{i \geq 6}\right)$, HOM monomers

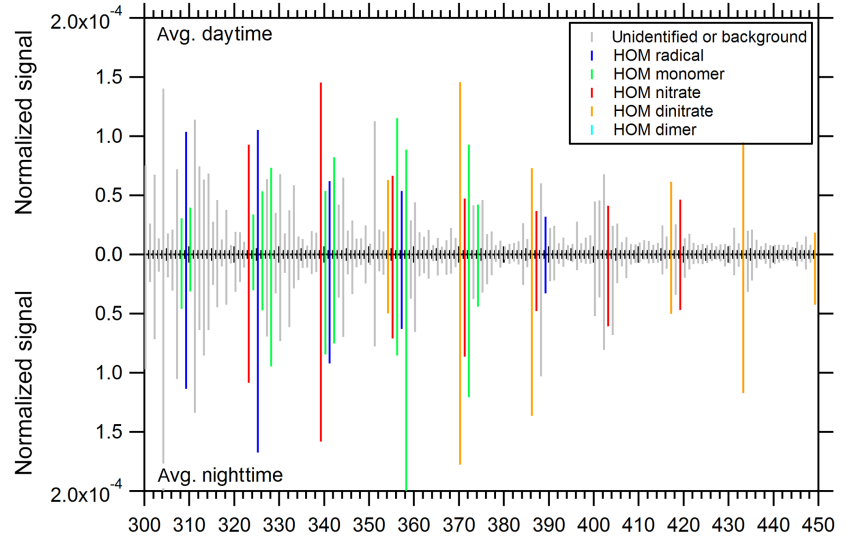

$\mathrm{m} / \mathrm{z}$

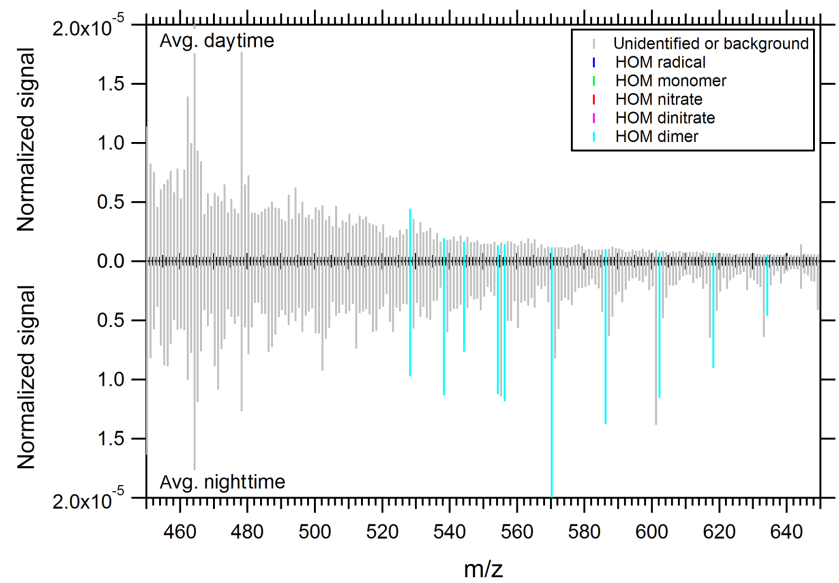

Figure 7. Comparison between average daytime and nighttime mass spectra measured with the nitrate CI-APi-TOF. The daytime spectrum was averaged for periods when no nucleation was observed.

$\left(\mathrm{C}_{10} \mathrm{H}_{14} \mathrm{O}_{i \geq 7}\right.$ and $\left.\mathrm{C}_{10} \mathrm{H}_{16} \mathrm{O}_{i \geq 6}\right)$ and HOMs involving reactions with nitrate $\left(\mathrm{C}_{10} \mathrm{H}_{15} \mathrm{NO}_{i \geq 7}\right.$ and $\mathrm{C}_{10} \mathrm{H}_{16} \mathrm{~N}_{2} \mathrm{O}_{i \geq 8}$; Jokinen et al., 2014). Dimers $\left(\mathrm{C}_{19} / \mathrm{C}_{20}\right.$ compounds) originate from reactions among $\mathrm{HOM} \mathrm{RO}_{2}$ radicals (Ehn et al., 2014).

The spectra were evaluated according to the peak list shown in Table 2 regarding HOMs. It should be noted that the listed compounds represent some fraction of the observed signal in the monomer and dimer region, although not all of the peaks that are present are identified yet. Figure 7 shows a comparison between the average daytime and the average nighttime spectra for the mass to charge range between $\mathrm{m} / \mathrm{z}$ 300 and 650. According to Fig. 7 the main difference between day and night is the significantly higher signals in the dimer region during the night.

Figure 8 shows the diurnal variation of the HOMs (separated into HOM radicals, HOM monomers, HOM nitrates and HOM dimers according to Table 2) together with other parameters ( $\mathrm{NO}, \mathrm{NO}_{2}, \mathrm{O}_{3}$ and global radiation). One striking feature is the pronounced maximum concentration of HOM dimers during the night. During the day, when the global ra- 
Table 2. Peak list of the highly oxidized organic molecules (HOMs) used in this study.

\begin{tabular}{|c|c|c|c|}
\hline Ion sum formula & Cluster ion & Exact mass & Compound \\
\hline $\mathrm{C}_{10} \mathrm{H}_{15} \mathrm{NO}_{9}^{-}$ & $\left(\mathrm{C}_{10} \mathrm{H}_{15} \mathrm{O}_{6}\right) \mathrm{NO}_{3}^{-}$ & 293.0752 & $\mathrm{HOM} \mathrm{RO}_{2}$ radical \\
\hline $\mathrm{C}_{10} \mathrm{H}_{15} \mathrm{NO}_{10}^{-}$ & $\left(\mathrm{C}_{10} \mathrm{H}_{15} \mathrm{O}_{7}\right) \mathrm{NO}_{3}^{-}$ & 309.0701 & $\mathrm{HOM} \mathrm{RO}_{2}$ radical \\
\hline $\mathrm{C}_{10} \mathrm{H}_{15} \mathrm{NO}_{11}^{-}$ & $\left(\mathrm{C}_{10} \mathrm{H}_{15} \mathrm{O}_{8}\right) \mathrm{NO}_{3}^{-}$ & 325.0651 & $\mathrm{HOM} \mathrm{RO}_{2}$ radical \\
\hline $\mathrm{C}_{10} \mathrm{H}_{15} \mathrm{NO}_{12}^{-}$ & $\left(\mathrm{C}_{10} \mathrm{H}_{15} \mathrm{O}_{9}\right) \mathrm{NO}_{3}^{-}$ & 341.0600 & $\mathrm{HOM} \mathrm{RO}_{2}$ radical \\
\hline $\mathrm{C}_{10} \mathrm{H}_{15} \mathrm{NO}_{13}^{-}$ & $\left(\mathrm{C}_{10} \mathrm{H}_{15} \mathrm{O}_{10}\right) \mathrm{NO}_{3}^{-}$ & 357.0549 & $\mathrm{HOM} \mathrm{RO}_{2}$ radical \\
\hline $\mathrm{C}_{10} \mathrm{H}_{15} \mathrm{NO}_{15}^{-}$ & $\left(\mathrm{C}_{10} \mathrm{H}_{15} \mathrm{O}_{12}\right) \mathrm{NO}_{3}^{-}$ & 389.0447 & $\mathrm{HOM} \mathrm{RO}_{2}$ radical \\
\hline $\mathrm{C}_{8} \mathrm{H}_{12} \mathrm{NO}_{11}^{-}$ & $\left(\mathrm{C}_{8} \mathrm{H}_{12} \mathrm{O}_{8}\right) \mathrm{NO}_{3}^{-}$ & 298.0416 & HOM monomer \\
\hline $\mathrm{C}_{9} \mathrm{H}_{14} \mathrm{NO}_{12}^{-}$ & $\left(\mathrm{C}_{9} \mathrm{H}_{14} \mathrm{O}_{9}\right) \mathrm{NO}_{3}^{-}$ & 328.0521 & HOM monomer \\
\hline $\mathrm{C}_{10} \mathrm{H}_{14} \mathrm{NO}_{10}^{-}$ & $\left(\mathrm{C}_{10} \mathrm{H}_{14} \mathrm{O}_{7}\right) \mathrm{NO}_{3}^{-}$ & 308.0623 & HOM monomer \\
\hline $\mathrm{C}_{10} \mathrm{H}_{14} \mathrm{NO}_{11}^{-}$ & $\left(\mathrm{C}_{10} \mathrm{H}_{14} \mathrm{O}_{8}\right) \mathrm{NO}_{3}^{-}$ & 324.0572 & HOM monomer \\
\hline $\mathrm{C}_{10} \mathrm{H}_{14} \mathrm{NO}_{12}^{-}$ & $\left(\mathrm{C}_{10} \mathrm{H}_{14} \mathrm{O}_{9}\right) \mathrm{NO}_{3}^{-}$ & 340.0521 & HOM monomer \\
\hline $\mathrm{C}_{10} \mathrm{H}_{14} \mathrm{NO}_{13}^{-}$ & $\left(\mathrm{C}_{10} \mathrm{H}_{14} \mathrm{O}_{10}\right) \mathrm{NO}_{3}^{-}$ & 356.0471 & HOM monomer \\
\hline $\mathrm{C}_{10} \mathrm{H}_{14} \mathrm{NO}_{14}^{-}$ & $\left(\mathrm{C}_{10} \mathrm{H}_{14} \mathrm{O}_{11}\right) \mathrm{NO}_{3}^{-}$ & 372.0420 & HOM monomer \\
\hline $\mathrm{C}_{10} \mathrm{H}_{16} \mathrm{NO}_{9}^{-}$ & $\left(\mathrm{C}_{10} \mathrm{H}_{16} \mathrm{O}_{6}\right) \mathrm{NO}_{3}^{-}$ & 294.0831 & HOM monomer \\
\hline $\mathrm{C}_{10} \mathrm{H}_{16} \mathrm{NO}_{10}^{-}$ & $\left(\mathrm{C}_{10} \mathrm{H}_{16} \mathrm{O}_{7}\right) \mathrm{NO}_{3}^{-}$ & 310.0780 & HOM monomer \\
\hline $\mathrm{C}_{10} \mathrm{H}_{16} \mathrm{NO}_{11}^{-}$ & $\left(\mathrm{C}_{10} \mathrm{H}_{16} \mathrm{O}_{8}\right) \mathrm{NO}_{3}^{-}$ & 326.0729 & HOM monomer \\
\hline $\mathrm{C}_{10} \mathrm{H}_{16} \mathrm{NO}_{12}^{-}$ & $\left(\mathrm{C}_{10} \mathrm{H}_{16} \mathrm{O}_{9}\right) \mathrm{NO}_{3}^{-}$ & 342.0678 & HOM monomer \\
\hline $\mathrm{C}_{10} \mathrm{H}_{16} \mathrm{NO}_{13}^{--}$ & $\left(\mathrm{C}_{10} \mathrm{H}_{16} \mathrm{O}_{10}\right) \mathrm{NO}_{3}^{-}$ & 358.0627 & HOM monomer \\
\hline $\mathrm{C}_{10} \mathrm{H}_{16} \mathrm{NO}_{14}^{-}$ & $\left(\mathrm{C}_{10} \mathrm{H}_{16} \mathrm{O}_{11}\right) \mathrm{NO}_{3}^{-}$ & 374.0576 & HOM monomer \\
\hline $\mathrm{C}_{10} \mathrm{H}_{15} \mathrm{~N}_{2} \mathrm{O}_{10}^{-}$ & $\left(\mathrm{C}_{10} \mathrm{H}_{15} \mathrm{NO}_{7}\right) \mathrm{NO}_{3}^{-}$ & 323.0732 & HOM nitrate \\
\hline $\mathrm{C}_{10} \mathrm{H}_{15} \mathrm{~N}_{2} \mathrm{O}_{11}^{-}$ & $\left(\mathrm{C}_{10} \mathrm{H}_{15} \mathrm{NO}_{8}\right) \mathrm{NO}_{3}^{-}$ & 339.0681 & HOM nitrate \\
\hline $\mathrm{C}_{10} \mathrm{H}_{15} \mathrm{~N}_{2} \mathrm{O}_{12}^{-}$ & $\left(\mathrm{C}_{10} \mathrm{H}_{15} \mathrm{NO}_{9}\right) \mathrm{NO}_{3}^{-}$ & 355.0630 & HOM nitrate \\
\hline $\mathrm{C}_{10} \mathrm{H}_{15} \mathrm{~N}_{2} \mathrm{O}_{13}^{-}$ & $\left(\mathrm{C}_{10} \mathrm{H}_{15} \mathrm{NO}_{10}\right) \mathrm{NO}_{3}^{-}$ & 371.0580 & HOM nitrate \\
\hline $\mathrm{C}_{10} \mathrm{H}_{15} \mathrm{~N}_{2} \mathrm{O}_{14}^{-}$ & $\left(\mathrm{C}_{10} \mathrm{H}_{15} \mathrm{NO}_{11}\right) \mathrm{NO}_{3}^{-}$ & 387.0529 & HOM nitrate \\
\hline $\mathrm{C}_{10} \mathrm{H}_{15} \mathrm{~N}_{2} \mathrm{O}_{15}^{-}$ & $\left(\mathrm{C}_{10} \mathrm{H}_{15} \mathrm{NO}_{12}\right) \mathrm{NO}_{3}^{-}$ & 403.0478 & HOM nitrate \\
\hline $\mathrm{C}_{10} \mathrm{H}_{15} \mathrm{~N}_{2} \mathrm{O}_{16}^{-}$ & $\left(\mathrm{C}_{10} \mathrm{H}_{15} \mathrm{NO}_{13}\right) \mathrm{NO}_{3}^{-}$ & 419.0427 & HOM nitrate \\
\hline $\mathrm{C}_{10} \mathrm{H}_{16} \mathrm{~N}_{3} \mathrm{O}_{11}^{-}$ & $\left(\mathrm{C}_{10} \mathrm{H}_{16} \mathrm{~N}_{2} \mathrm{O}_{8}\right) \mathrm{NO}_{3}^{-}$ & 354.0790 & HOM dinitrate \\
\hline $\mathrm{C}_{10} \mathrm{H}_{17} \mathrm{~N}_{4} \mathrm{O}_{14}^{-}$ & $\left(\mathrm{C}_{10} \mathrm{H}_{16} \mathrm{~N}_{2} \mathrm{O}_{8}\right)\left(\mathrm{HNO}_{3}\right) \mathrm{NO}_{3}^{-}$ & 417.0747 & HOM dinitrate \\
\hline $\mathrm{C}_{10} \mathrm{H}_{16} \mathrm{~N}_{3} \mathrm{O}_{12}^{-}$ & $\left(\mathrm{C}_{10} \mathrm{H}_{16} \mathrm{~N}_{2} \mathrm{O}_{9}\right) \mathrm{NO}_{3}^{-}$ & 370.0739 & HOM dinitrate \\
\hline $\mathrm{C}_{10} \mathrm{H}_{17} \mathrm{~N}_{4} \mathrm{O}_{15}^{-}$ & $\left(\mathrm{C}_{10} \mathrm{H}_{16} \mathrm{~N}_{2} \mathrm{O}_{9}\right)\left(\mathrm{HNO}_{3}\right) \mathrm{NO}_{3}^{-}$ & 433.0696 & HOM dinitrate \\
\hline $\mathrm{C}_{10} \mathrm{H}_{16} \mathrm{~N}_{3} \mathrm{O}_{13}^{-}$ & $\left(\mathrm{C}_{10} \mathrm{H}_{16} \mathrm{~N}_{2} \mathrm{O}_{10}\right) \mathrm{NO}_{3}^{-}$ & 386.0689 & HOM dinitrate \\
\hline $\mathrm{C}_{10} \mathrm{H}_{17} \mathrm{~N}_{4} \mathrm{O}_{16}^{-}$ & $\left(\mathrm{C}_{10} \mathrm{H}_{16} \mathrm{~N}_{2} \mathrm{O}_{10}\right)\left(\mathrm{HNO}_{3}\right) \mathrm{NO}_{3}^{-}$ & 449.0645 & HOM dinitrate \\
\hline $\mathrm{C}_{19} \mathrm{H}_{30} \mathrm{NO}_{16}^{-}$ & $\left(\mathrm{C}_{19} \mathrm{H}_{30} \mathrm{O}_{13}\right) \mathrm{NO}_{3}^{-}$ & 528.1570 & HOM dimer \\
\hline $\mathrm{C}_{19} \mathrm{H}_{30} \mathrm{NO}_{17}^{-}$ & $\left(\mathrm{C}_{19} \mathrm{H}_{30} \mathrm{O}_{14}\right) \mathrm{NO}_{3}^{-}$ & 544.1519 & HOM dimer \\
\hline $\mathrm{C}_{20} \mathrm{H}_{28} \mathrm{NO}_{16}^{--}$ & $\left(\mathrm{C}_{20} \mathrm{H}_{28} \mathrm{O}_{13}\right) \mathrm{NO}_{3}^{-}$ & 538.1414 & HOM dimer \\
\hline $\mathrm{C}_{20} \mathrm{H}_{28} \mathrm{NO}_{17}^{-}$ & $\left(\mathrm{C}_{20} \mathrm{H}_{28} \mathrm{O}_{14}\right) \mathrm{NO}_{3}^{-}$ & 554.1363 & HOM dimer \\
\hline $\mathrm{C}_{20} \mathrm{H}_{28} \mathrm{NO}_{18}^{-1}$ & $\left(\mathrm{C}_{20} \mathrm{H}_{28} \mathrm{O}_{15}\right) \mathrm{NO}_{3}^{-}$ & 570.1312 & HOM dimer \\
\hline $\mathrm{C}_{20} \mathrm{H}_{28} \mathrm{NO}_{19}^{-0}$ & $\left(\mathrm{C}_{20} \mathrm{H}_{28} \mathrm{O}_{16}\right) \mathrm{NO}_{3}^{-}$ & 586.1261 & HOM dimer \\
\hline $\mathrm{C}_{20} \mathrm{H}_{28} \mathrm{NO}_{20}^{-}$ & $\left(\mathrm{C}_{20} \mathrm{H}_{28} \mathrm{O}_{17}\right) \mathrm{NO}_{3}^{-}$ & 602.1210 & HOM dimer \\
\hline $\mathrm{C}_{20} \mathrm{H}_{28} \mathrm{NO}_{21}^{-20}$ & $\left(\mathrm{C}_{20} \mathrm{H}_{28} \mathrm{O}_{18}\right) \mathrm{NO}_{3}^{-}$ & 618.1159 & HOM dimer \\
\hline $\mathrm{C}_{20} \mathrm{H}_{28} \mathrm{NO}_{22}^{-1}$ & $\left(\mathrm{C}_{20} \mathrm{H}_{28} \mathrm{O}_{19}\right) \mathrm{NO}_{3}^{-}$ & 634.1108 & HOM dimer \\
\hline $\mathrm{C}_{20} \mathrm{H}_{28} \mathrm{NO}_{23}^{-2}$ & $\left(\mathrm{C}_{20} \mathrm{H}_{28} \mathrm{O}_{20}\right) \mathrm{NO}_{3}^{-}$ & 650.1058 & HOM dimer \\
\hline $\mathrm{C}_{20} \mathrm{H}_{30} \mathrm{NO}_{17}^{-}$ & $\left(\mathrm{C}_{20} \mathrm{H}_{30} \mathrm{O}_{14}\right) \mathrm{NO}_{3}^{-}$ & 556.1519 & HOM dimer \\
\hline
\end{tabular}

diation shows values above zero, the dimer signals drop by about 1 order of magnitude and reach levels which are close to the detection limit of the instrument. The low daytime dimer concentrations are probably due to enhanced $\mathrm{NO}, \mathrm{HO}_{2}$ and $\mathrm{R}^{\prime} \mathrm{O}_{2}$ concentrations during the day. These compounds can react with $\mathrm{HOM} \mathrm{RO}_{2}$ radicals and thereby inhibit the for- mation of dimers, which are a result of the reaction between two $\mathrm{RO}_{2}$ radicals. As can be seen from Fig. 8, the NO concentration peaks in the morning. $\mathrm{HO}_{2}$ was not measured but typically peaks around noon or in the later afternoon (Monks, 2005). Direct photolysis of HOM dimers has to our knowl- 


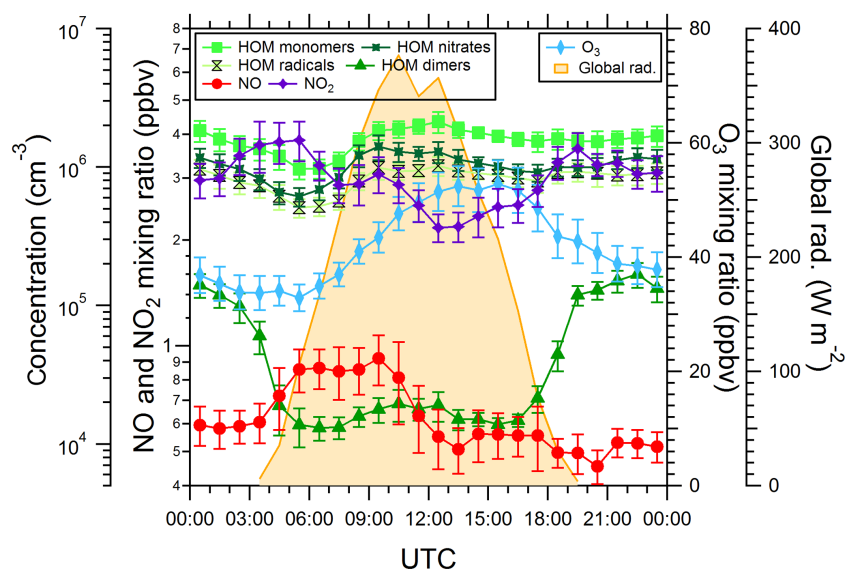

Figure 8. Diurnal profiles of the $\mathrm{NO}, \mathrm{NO}_{2}$ and $\mathrm{O}_{3}$ mixing ratios. The signals for highly oxidized organic molecules (HOMs) are shown for some $\mathrm{C}_{10}$ (HOM monomers, HOM nitrates and HOM radicals) and $\mathrm{C}_{19} / \mathrm{C}_{20}$ compounds (HOM dimers), which show a distinct maximum during the night. The HOM dinitrates show a similar pattern as the other $\mathrm{C}_{10}$ compounds and are not included in the figure. The global radiation is shown in addition. Error bars indicate 1 standard deviation for the $30 \mathrm{~min}$ averages.

edge not been reported in the literature but could in principle also explain the dimer pattern seen in Fig. 8.

The HOM monomer signal (Fig. 8) does not show a pronounced diurnal cycle; only in the early morning are the signals reduced by about $50 \%$ compared to the daily average. Slightly higher values around noon could be explained by the higher $\mathrm{O}_{3}$ and $\mathrm{OH}$ concentrations during midday, which lead to enhanced formation of HOMs through reactions between these compounds and monoterpenes (Jokinen et al., 2015; Kirkby et al., 2016). The HOM nitrates, dinitrates and radicals show almost the same profile as the HOM monomers. This might be expected for the HOM radicals as these can be regarded as the precursors for the HOM monomers, but the fact that the HOM nitrates follow an almost identical pattern is somewhat surprising as the NO mixing ratio shows a different profile and is thought to be involved in the formation of the HOM nitrates. However, further involvement of, for example, $\mathrm{OH}, \mathrm{HO}_{2}$ and $\mathrm{R}^{\prime} \mathrm{O}_{2}$ in the $\mathrm{HOM}$ formation should also play a role and therefore influence their diurnal pattern. The elucidation of the HOM formation mechanisms is beyond the scope of this article and will therefore not be discussed further. More field and chamber experiments are needed to identify the influence of different trace gases and radicals on the formation and concentration of HOMs.

\subsection{Particle formation rates}

The presence of small particles $(<\sim 20 \mathrm{~nm})$ was observed on almost every day during the campaign. However, often nanometer-sized particles appeared suddenly without clear growth from the smallest size the nDMA covered (slightly above $3 \mathrm{~nm}$ ). In total there were seven events where clear growth was detectable, and these events were the only ones for which a NPF rate $(J)$ was derived. It should be noted that clear NPF was observed only on 6 days; however, for one day two NPF rates were derived, which results in a total of seven NPF rates.

In accordance with other previous studies (Metzger et al., 2010; Kirkby et al., 2011), we have first derived a NPF rate at a larger mobility diameter $d_{p 2}(2.5 \mathrm{~nm}$ in the present study), which was corrected to a smaller diameter of $d_{p 1}=1.7 \mathrm{~nm}$ in a second step. The formation rate $J_{d p 2}$ is obtained from the time derivative of the small particle concentration, which follows from the difference in particle concentrations $\left(N_{2.5-10}\right)$ measured by the TSI model 3776 (cut-off diameter of $2.5 \mathrm{~nm}$ ) and 3010 (cut-off diameter of $10 \mathrm{~nm}$ ) CPCs:

$$
\begin{aligned}
J_{d_{p 2}} & =\frac{\mathrm{d} N_{2.5-10}}{\mathrm{~d} t} \\
& +\mathrm{CS}_{d_{p 2}} \cdot N_{2.5-10}+\frac{\mathrm{GR}}{10 \mathrm{~nm}-2.5 \mathrm{~nm}} \cdot N_{2.5-10} .
\end{aligned}
$$

The second term on the right-hand side in Eq. (7) accounts for the loss of small particles on particles larger than $2.5 \mathrm{~nm}$, while the third term accounts for the growth of particles out of the size range under consideration (Kulmala et al., 2012). The coagulation sink $\mathrm{CS}_{d p 2}$ is calculated from the particle size distribution measured by the nDMA and the SMPS. The second step involves an exponential correction to obtain the particle formation rate at the smaller size, $J_{d p 1}$, by taking into account the coagulation sink and the growth rate (GR) of particles (Lehtinen et al., 2007):

$J_{d_{p 1}}=J_{d_{p 2}} \cdot \exp \left(\frac{\mathrm{CS}_{d_{p 1}}}{\mathrm{GR}} \cdot \mathrm{d} p_{1} \cdot \gamma\right)$.

The factor $\gamma$ is defined as follows (Lehtinen et al., 2007):

$\gamma=\frac{1}{s+1} \cdot\left(\left(\frac{d_{p 2}}{d_{p 1}}\right)^{s+1}-1\right)$

where $s$ is the slope of the coagulation sink as a function of size for the size range between $d_{p 1}$ and $d_{p 2}$ $\left(s=\log \left(\mathrm{CS}_{d p 2} / \mathrm{CS}_{d p 1}\right) / \log \left(d_{p 2} / d_{p 1}\right)\right)$. The value of $s$ can be derived from the measured particle size distribution and was found to be around -1.6 for the present study, which is in good agreement with the values reported by Lehtinen et al. (2007). The growth rate was derived from the nDMA measurements in the size range between 3 and $10 \mathrm{~nm}$ by fitting a Gaussian function to the particle size distribution to determine the mode diameter for all measured size distributions. Applying a linear fit to the mode diameter as a function of time yields the GR used in Eq. (8) (Hirsikko et al., 2005). Errors are calculated by taking into account the statistical variation of the particle formation rates $J_{d p 2}$ as well as systematic errors on GR (factor of 2), $d_{p 2}$ (factor of 1.3) and CS (factor of 1.5). 


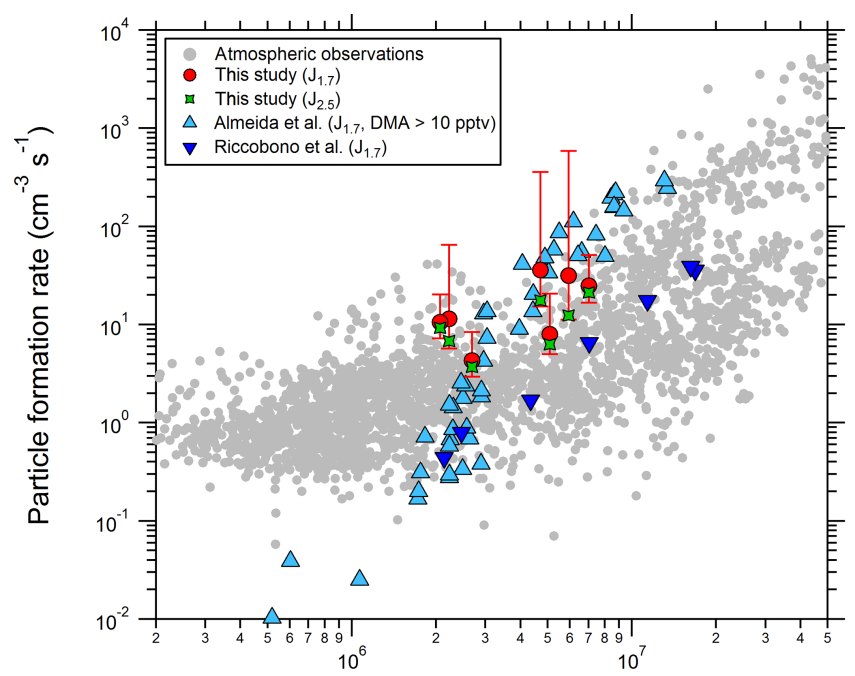

Sulfuric acid monomer concentration $\left(\mathrm{cm}^{-3}\right)$

Figure 9. Particle formation rates from this study at a mobility diameter of $1.7 \mathrm{~nm}\left(J_{1.7}\right.$, red circles $)$ and $2.5 \mathrm{~nm}\left(J_{2.5}\right.$, green stars $)$. Data from CLOUD chamber measurements for a diameter of $1.7 \mathrm{~nm}$ are shown in addition for the system of sulfuric acid, water and dimethylamine (light blue symbols; see Almeida et al., 2013) and sulfuric acid, water and oxidized organics from pinanediol (dark blue symbols; see Riccobono et al., 2014). The light-gray circles are from other field measurements (Kuang et al., 2008; Paasonen et al., 2010; Kulmala et al., 2013).

Figure 9 shows a comparison between $J_{d p 1}$ from this study, data from other field studies and formation rates from CLOUD chamber studies for the system of sulfuric acid, dimethylamine and water at $278 \mathrm{~K}$ (Almeida et al., 2013), as well as for oxidized organic compounds with sulfuric acid and water (Riccobono et al., 2014).

\section{Discussion}

By comparing time periods where significant NPF occurred to time periods where no NPF was observed, some conclusions can be drawn about the relevance of certain parameters regarding NPF. Figure 10 shows a comparison for a variety of parameters by comparing nucleation days to no-nucleation days (red bars) and periods with high sulfuric acid dimer concentrations to no-nucleation days when there are also no high dimer concentrations (blue bars).

It is evident from Fig. 10 that sulfuric acid is on average a factor of 2 to 2.5 higher on days with nucleation; however, the variability is rather high (error bars take into account the standard deviations of a parameter for both the nucleation days and the no-nucleation days). The enhanced sulfuric acid concentrations confirm the importance of this compound regarding NPF, which has also been shown in numerous other studies (e.g., Weber et al., 1997; Kulmala et al., 2004; Fiedler et al., 2005; Kuang et al., 2008). The OH con-

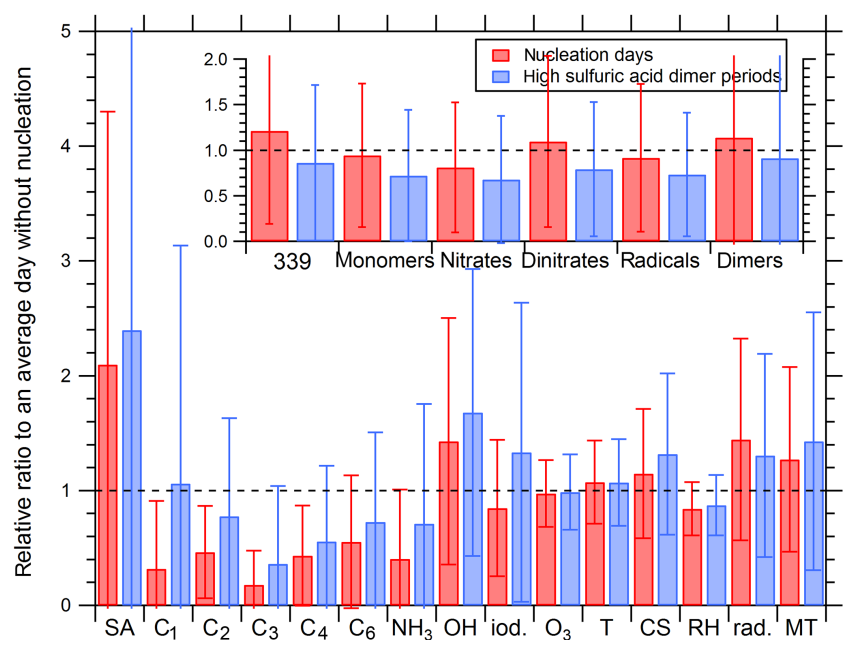

Figure 10. Comparison of various parameters for different time periods ( $\mathrm{SA}$ : sulfuric acid monomer; $\mathrm{C}_{1}, \mathrm{C}_{2}, \mathrm{C}_{3}, \mathrm{C}_{4}$ and $\mathrm{C}_{6}$ : amines; iod.: iodic acid; and rad.: global radiation intensity). The subset figure on the upper right shows the signals for the highly oxidized organic compounds with 10 or 20 carbon atoms (339: organic compound $\mathrm{C}_{10} \mathrm{H}_{15} \mathrm{NO}_{8}$ clustered with $\mathrm{NO}_{3}^{-}$having a mass of $339.0681 \mathrm{Th}$; the definition of other HOMs, i.e., monomers, radicals, nitrates, dinitrates and dimers, can be found in Table 2). The red bars relate nucleation days to days without nucleation and the blue bars show the ratio between periods where high sulfuric acid dimer concentrations were observed (see Fig. 6) to no-nucleation days. Similar times of the day (early morning) were used as reference periods when no nucleation was observed as nucleation and dimer formation was also mainly observed in the morning.

centration and the global radiation are also enhanced during nucleation, which is not surprising given the fact that the parameters $\mathrm{H}_{2} \mathrm{SO}_{4}, \mathrm{OH}$ and global radiation are connected. The relative humidity is generally lower during nucleation periods, which has also been reported in previous studies (Hamed et al., 2011; Nieminen et al., 2015).

Regarding amines and ammonia, Fig. 10 reveals an anticorrelation between their concentration and the occurrence of NPF or sulfuric acid dimer formation (factor of 2 to 5 lower during nucleation). However, this does not necessarily mean that these compounds inhibit the formation of particles. On the contrary, it could mean that amines and ammonia are efficiently taken up by small clusters and therefore are also involved in the formation of new particles. Unlike sulfuric acid, amines and ammonia are not produced in the gas phase and therefore their concentration will decrease with increasing distance from their sources depending on the condensation sink. During nucleation the condensation sink is slightly enhanced (Fig. 10), probably because of the newly formed particles. However, the CS is only calculated for particles larger than $3 \mathrm{~nm}$. Also, smaller particles and sulfuric acid clusters can contain amines (Kürten et al., 2014) and even the sulfuric acid monomer can be bound to dimethylamine (Ortega et al., 2012; Kürten et al., 2014). Therefore, 
continuous production of sulfuric acid and its clusters will lead to a depletion of amines away from their sources, although no mixed clusters of sulfuric acid and amines could be observed; this is probably the case because their concentrations were too low to be measured with the CI-APi-TOF. As sulfuric acid concentrations are high during nucleation, this could explain the low amine values. Efficient uptake of amines in the particle phase has also been reported in a previous field study (You et al., 2014). In addition, the limited pool of amines can also be the explanation for the relatively low slope from Fig. 6 (sulfuric acid dimer vs. monomer) for some of the periods with elevated sulfuric acid dimer concentrations. If the sulfuric acid concentration increases, the ratio of the free (unbound) amine to sulfuric acid concentration drops, and there are fewer amines available to stabilize the sulfuric acid dimers. This is a different situation compared to the CLOUD7 experiment, where the amine to sulfuric acid concentration was maintained at a ratio of $\sim 100$ over the entire duration of the experiments (Kürten et al., 2014). However, from these observations we cannot unambiguously conclude whether the amines are involved in the very first steps of nucleation, or whether they are depleted due to clusters which do not need the help of amines in order to nucleate. One other aspect that could explain the low amine ratios is the somewhat enhanced $\mathrm{OH}$ concentration during the nucleation days, as amines react with $\mathrm{OH}$. However, the lifetime of amines regarding their reactions with $\mathrm{OH}$ is on the order of hours (Ge et al., 2011), whereas the uptake on particles is significantly faster (if CS is on the order of $10^{-3}$ to $10^{-2} \mathrm{~s}^{-1}$ ).

Regarding the possibility that sulfuric acid and amines can explain the observed nucleation, it has to be noted that no clusters involving more than two sulfuric acid molecules could be observed. In the following we will calculate the maximum expected sulfuric acid trimer concentration and discuss what parameters can lower this concentration. The maximum measured sulfuric acid dimer concentration is around $1 \times 10^{5}$ molecules $\mathrm{cm}^{-3}$ for a sulfuric acid monomer concentration of $1 \times 10^{7}$ molecules $\mathrm{cm}^{-3}$. A sulfuric acid trimer will be formed through the collision between a monomer and a dimer (collision rate $K_{1,2}$ ), whereas the loss rate of the trimer is defined by the sum of the condensation sink (CS) and its evaporation rate $\left(k_{e, 3}\right)$. At steady state this would yield the following equation for the trimer concentration $N_{3}$ as function of the monomer and dimer concentrations $N_{1}$ and $N_{2}$ (for simplicity this neglects a potential contribution from tetramer evaporation):

$N_{3}=\frac{K_{1,2} \cdot N_{1} \cdot N_{2}}{\mathrm{CS}+k_{e, 3}}$.

Using a value of $5 \times 10^{-10}$ molecule ${ }^{-1} \mathrm{~cm}^{3} \mathrm{~s}^{-1}$ for $K_{1,2}$ and a condensation sink (CS) of $5 \times 10^{-3} \mathrm{~s}^{-1}$ for the abovementioned monomer and dimer concentrations would yield a trimer concentration of $1 \times 10^{5}$ molecules $\mathrm{cm}^{-3}$ if the trimer evaporation rate were zero. This concentration should be detectable with our CI-APi-TOF. The fact that we do not see the trimer could indicate that the trimer evaporation rate is nonzero. For a high amine to sulfuric acid ratio nucleation proceeds at or close to the kinetic limit (Jen et al., 2014; Kürten et al., 2014). However, if the amine concentration is not very high, not every trimer that is formed would be stable (as it is the case for a favored acid-base ratio; see Ortega et al., 2012) and therefore could evaporate rapidly. This would result in lower trimer concentrations, which could be below the detection limit of the CI-APi-TOF. From this perspective the absence of larger sulfuric acid amine clusters is not necessarily an indication that this system is not responsible for NPF. In other regions where the sulfuric acid and amine mixing ratios are even higher (i.e., very close to amine sources) such clusters can be observable (Zhao et al., 2011). Recently, Jen et al. (2016b) provided evidence that nitrate chemical ionization could not be sensitive towards sulfuric acid-amine or sulfuric acid-diamine clusters if these contain three or more sulfuric acid molecules because of the lowered acidity of such clusters by the basic amines/diamines. This could also explain the absence of clusters beyond the dimer in the present study. Further measurements using different primary ions are needed to investigate this possibility further.

The $\mathrm{C}_{10}$ and $\mathrm{C}_{20}$ signals for NPF and no-nucleation days are not significantly different (Fig. 10). This can be interpreted in different ways: (1) the HOMs are not important in terms of NPF, (2) HOMs are generally high enough and it needs just enough sulfuric acid to initiate nucleation involving HOMs, or (3) "HOM" is too broadly defined and only a subgroup of HOMs is involved in the nucleation, but currently we cannot distinguish this group. Neither of the possibilities can be proven right or wrong. However, what can be said is that it is unlikely that the identified HOMs alone are capable of producing new particles to a significant extent at the conditions of the present study. The HOM dimer concentrations (Fig. 8) are significantly higher during the night than during the day. Nevertheless, no nighttime nucleation is observed. This could be interpreted as an indication that if HOMs are involved in NPF, it requires additional compounds such as sulfuric acid to initiate significant nucleation. Alternative explanations for the absence of nighttime nucleation could be the suppression of the formation of HOMs that can nucleate by $\mathrm{NO}_{3}$ during the night, or low $[\mathrm{OH}]$, which is required for the formation of nucleating $\mathrm{HOMs}$.

Kulmala et al. (2013) proposed that $\mathrm{C}_{10} \mathrm{H}_{15} \mathrm{NO}_{8}$ (detected as a cluster with $\mathrm{NO}_{3}^{-}$at $339.0681 \mathrm{Th}$ ) could be important because NPF correlated even better with this compound compared to sulfuric acid. During nucleation days this compound is only slightly elevated (Fig. 10), and this could be due to the generally higher $\mathrm{OH}$ levels, although the exact formation mechanism of $\mathrm{C}_{10} \mathrm{H}_{15} \mathrm{NO}_{8}$ has to our knowledge not been reported yet. During nucleation, no mixed clusters between sulfuric acid and HOMs could be identified. However, this also does not rule out their existence as the concentrations could be below the CI-APi-TOF detection limit, or a low charging 
efficiency with the nitrate primary ion could prevent their detection. Furthermore, not all signals are identified yet.

The observed particle formation rates (Fig. 9) are consistent with the rates observed at other sites, although at the upper end of the typical ranges that have been previously measured. The present data seem to agree a bit better with CLOUD chamber data for the system of sulfuric acid, water and dimethylamine (Almeida et al., 2013) compared to data for the system of sulfuric acid, water and oxidized organics from pinanediol (Riccobono et al., 2014). However, a direct comparison is difficult as the conditions between this ambient study and the CLOUD chamber experiments are not identical (with respect to $T$, RH, CS, amine mixing ratios, HOM concentrations, etc.).

\section{Summary}

In spring 2014 (18 May to 7 June) a field campaign was conducted at a rural site in central Germany (Vielbrunn/Odenwald). The measurement site was in the vicinity (within 450 to $1100 \mathrm{~m}$ distance) of three larger dairy farms. The aim of this campaign was to evaluate whether there is a connection between NPF and the concentration of amines and/or ammonia. Furthermore, the impact of highly oxidized organic molecules (HOMs) from surrounding forests was investigated. A nitrate chemical ionization-atmospheric pressure interface time-of-flight mass spectrometer (CI-APiTOF) was used to identify gas-phase compounds and clusters. Particle counters and differential mobility analyzers were used to characterize the aerosol size distribution and number density. The following conclusions can be drawn from our measurements:

- Nitrate CI-APi-TOF can be used to measure sulfuric acid, iodic acid, amines, a nitrosamine, ammonia and HOMs. The measurement of iodic acid, ammonia and the nitrosamine has not been described before; therefore, the method is even more versatile than previously thought and well suited to studying all of the abovementioned compounds during field measurements.

- The sulfuric acid concentration can be well described by proxies $\left(\mathrm{SO}_{2}\right.$, global radiation, $\mathrm{RH}$ and $\mathrm{CS}$ or just by $\mathrm{SO}_{2}$ and global radiation) for this site, with a similar accuracy to that reported in a previous study (Mikkonen et al., 2011).

- Significant sulfuric acid dimer concentrations were measured. It is, however, not clear what compound stabilizes the neutral dimers. Larger sulfuric acid clusters (trimer and beyond) were not observed.

- Amines $\left(\mathrm{C}_{1}, \mathrm{C}_{2}, \mathrm{C}_{3}, \mathrm{C}_{4}\right.$ and $\mathrm{C}_{6}$ amines $)$ are present at estimated mixing ratios between approximately 1 and 5 pptv, which is consistent with other studies; the $\mathrm{C}_{4}$ and
$\mathrm{C}_{6}$ amines as well as ammonia show a diurnal variation, which follows the temperature profile.

- Iodine was observed (probably iodic acid) on every day, which is somewhat surprising for a continental site located more than $400 \mathrm{~km}$ away from the ocean. The nitrate CI-APi-TOF has a high sensitivity towards iodic acid and its presence indicates long-range transport of iodine-containing substances (although a local source cannot entirely be ruled out). OIO concentrations can also be estimated using $\mathrm{OH}$ concentrations; however, both $\left[\mathrm{HIO}_{3}\right]\left(\sim 3 \times 10^{5}\right.$ molecules $\left.\mathrm{cm}^{-3}\right)$ and [OIO] $\left(\sim 5 \times 10^{6}\right.$ molecules $\left.\mathrm{cm}^{-3}\right)$ are probably too low to affect NPF significantly at this site.

- The diurnal pattern of HOM dimers shows maximum concentrations during the night but no nighttime nucleation is observed; the daytime concentration could be low due to the presence of $\mathrm{NO}$ and/or $\mathrm{HO}_{2}$, which suppress the HOM dimer formation.

- Relatively high particle formation rates are found, which are rather at the upper end of the atmospheric observations for other rural sites; the rates are compatible with CLOUD chamber data both for the systems of sulfuric acid, water and dimethylamine (Almeida et al., 2013) and for a system involving sulfuric acid, water and oxidized organics (Riccobono et al., 2014). No definitive answer can be given as to which system is more relevant.

- Nucleation seems to be favored on days with relatively low RH and high sulfuric acid. An anti-correlation with the amine and ammonia signals is observed; this could be due to efficient uptake of these compounds on clusters and particles during NPF as amines and ammonia are not produced in the gas phase.

The above points seem to support recent findings about the relevance of amines in terms of NPF and early growth (Chen et al., 2012; Almeida et al., 2013; Kulmala et al., 2013; Lehtipalo et al., 2016). However, it cannot be unambiguously concluded that amines are more relevant for NPF than HOMs at this site because no nucleating clusters could be directly observed. More studies like the present one are necessary in the future to obtain better statistics about the parameters relevant for NPF (Fig. 10). Ideally, such measurements should include further instrumentation, including a particle size magnifier (Vanhanen et al., 2011) for the measurement of clusters and small particles $(<3 \mathrm{~nm})$, an APi-TOF (Junninen et al., 2010) for identification of charged nucleating clusters, an instrument for $\mathrm{HO}_{x} / \mathrm{RO}_{x}$ measurements and an instrument for sensitive amine measurements capable of speciating the amines. 


\section{Data availability}

All data presented in this study are available upon request from the corresponding author.

Acknowledgements. We thank the German Weather Service (Deutscher Wetterdienst, DWD) for providing infrastructure and meteorological data. Funding from the German Federal Ministry of Education and Research (grant no. 01LK1222A) and the Marie Curie Initial Training Network "CLOUD-TRAIN" (grant no. 316662 ) is gratefully acknowledged.

Edited by: T. Karl

Reviewed by: two anonymous referees

\section{References}

Aljawhary, D., Lee, A. K. Y., and Abbatt, J. P. D.: High-resolution chemical ionization mass spectrometry (ToF-CIMS): application to study SOA composition and processing, Atmos. Meas. Tech., 6, 3211-3224, doi:10.5194/amt-6-3211-2013, 2013.

Almeida, J., Schobesberger, S., Kürten, A., Ortega, I. K., Kupiainen-Määttä, O., Praplan, A. P., Adamov, A., Amorim, A., Bianchi, F., Breitenlechner, M., David, A., Dommen, J., Donahue, N. M., Downard, A., Dunne, E. M., Duplissy, J., Ehrhart, S., Flagan, R. C., Franchin, A., Guida, R., Hakala, J., Hansel, A., Heinritzi, M., Henschel, H., Jokinen, T., Junninen, H., Kajos, M., Kangasluoma, J., Keskinen, H., Kupc, A., Kurtén, T., Kvashin, A. N., Laaksonen, A., Lehtipalo, K., Leiminger, M., Leppä, J., Loukonen, V., Makhmutov, V., Mathot, S., McGrath, M. J., Nieminen, T., Olenius, T., Onnela, A., Petäjä, T., Riccobono, F., Riipinen, I., Rissanen, M., Rondo, L., Ruuskanen, T., Santos, F. D., Sarnela, N., Schallhart, S., Schnitzhofer, R., Seinfeld, J. H., Simon, M., Sipilä, M., Stozhkov, Y., Stratmann, F., Tomé, A., Tröstl, J., Tsagkogeorgas, G., Vaattovaara, P., Viisanen, Y., Virtanen, A., Vrtala, A., Wagner, P. E., Weingartner, E., Wex, H., Williamson, C., Wimmer, D., Ye, P., Yli-Juuti, T., Carslaw, K. S., Kulmala, M., Curtius, J., Baltensperger, U., Worsnop, D. R., Vehkamäki, H., and Kirkby, J.: Molecular understanding of sulphuric acid-amine particle nucleation in the atmosphere, Nature, 502, 359-363, doi:10.1038/nature12663, 2013.

Berndt, T., Jokinen, T., Sipilä, M., Mauldin III, R. L. Herrmann, H., Stratmann, F., Junninen, H., and Kulmala, M: $\mathrm{H}_{2} \mathrm{SO}_{4}$ formation from the gas-phase reaction of stabilized Criegee Intermediates with $\mathrm{SO}_{2}$ : Influence of water vapour content and temperature, Atmos. Environ., 89, 603-612, doi:10.1016/j.atmosenv.2014.02.062, 2014.

Berresheim, H., Elste, T., Plass-Dülmer, C., Eisele, F. L., and Tanner, D. J.: Chemical ionization mass spectrometer for long-term measurements of atmospheric $\mathrm{OH}$ and $\mathrm{H}_{2} \mathrm{SO}_{4}$, Int. J. Mass Spectrom., 202, 91-109, doi:10.1016/S1387-3806(00)00233-5, 2000.

Bianchi, F., Tröstl, J., Junninen, H., Frege, C., Henne, S., Hoyle, C. R., Molteni, U., Herrmann, E., Adamov, A., Bukowiecki, N., Chen, X., Duplissy, J., Gysel, M., Hutterli, M., Kangasluoma, J., Kontkanen, J., Kürten, A., Manninen, H. E., Münch, S., Peräkylä, O., Petäjä, T., Rondo, L., Williamson, C., Weingartner, E., Curtius, J., Worsnop, D. R., Kulmala, M., Dommen, J., and Baltensperger, U.: New particle formation in the free troposphere:
A question of chemistry and timing, Science, 352, 1109-1112, doi:10.1126/science.aad5456, 2016.

Blake, R. S., Monks, P. S., and Ellis, A. M.: Proton-Transfer Reaction Mass Spectrometry, Chem. Rev., 109, 861-896, doi:10.1021/cr800364q, 2009.

Boy, M., Mogensen, D., Smolander, S., Zhou, L., Nieminen, T., Paasonen, P., Plass-Dülmer, C., Sipilä, M., Petäjä, T., Mauldin, L., Berresheim, H., and Kulmala, M.: Oxidation of SO2 by stabilized Criegee intermediate ( $\mathrm{sCI}$ ) radicals as a crucial source for atmospheric sulfuric acid concentrations, Atmos. Chem. Phys., 13, 3865-3879, doi:10.5194/acp-13-3865-2013, 2013.

Cappellin, L., Karl, T., Probst, M., Ismailova, O., Winkler, P. M., Soukoulis, C., Aprea, E., Märk, T. D., Gasperi, F., and Biasioli, F.: On quantitative determination of volatile organic compound concentrations using proton transfer reaction time-offlight mass spectrometry, Environ. Sci. Technol., 46, 2283-2290, doi:10.1021/es203985t, 2012.

Chang, D., Song, Y., and Liu, B.: Visibility trends in six megacities in China 1973-2007, Atmos. Res., 94, 161-167, doi:10.1016/j.atmosres.2009.05.006, 2009.

Chen, M., Titcombe, M., Jiang, J., Jen, C., Kuang, C., Fischer, M. L., Eisele, F. L., Siepmann, J. I., Hanson, D. R., Zhao, J., and McMurry, P. H.: Acid-base chemical reaction model for nucleation rates in the polluted atmospheric boundary layer, P. Natl. Acad. Sci. USA, 109, 18713-18718, doi:10.1073/pnas.1210285109, 2012.

Crounse, J. D., Nielsen, L. B., Jørgensen, S., Kjaergaard, H. G., and Wennberg, P. O.: Autooxidation of organic compounds in the atmosphere, J. Phys. Chem. Lett., 4, 3513-3520, doi:10.1021/jz4019207, 2013.

Ehn, M., Kleist, E., Junninen, H., Petäjä, T., Lönn, G., Schobesberger, S., Dal Maso, M., Trimborn, A., Kulmala, M., Worsnop, D. R., Wahner, A., Wildt, J., and Mentel, Th. F.: Gas phase formation of extremely oxidized pinene reaction products in chamber and ambient air, Atmos. Chem. Phys., 12, 5113-5127, doi:10.5194/acp-12-5113-2012, 2012.

Ehn, M., Thornton, J. A., Kleist, E., Sipilä, M., Junninen, H., Pullinen, I., Springer, M., Rubach, F., Tillmann, R., Lee, B., LopezHilfiker, F., Andres, S., Acir, I.-H., Rissanen, M., Jokinen, T., Schobesberger, S., Kangasluoma, J., Kontkanen, J., Nieminen, T., Kurtén, T., Nielsen, L. B., Jørgensen, S., Kjaergaard, H. G., Canagaratna, M., Dal Maso, M., Berndt, T., Petäjä, T., Wahner, A., Kerminen, V.-M., Kulmala, M., Worsnop, D. R., Wildt, J., and Mentel, T. F.: A large source of low-volatility secondary organic aerosol, Nature, 506, 476-479, doi:10.1038/nature13032, 2014.

Eisele, F. L. and Tanner, D. J.: Measurement of the gas phase concentration of $\mathrm{H}_{2} \mathrm{SO}_{4}$ and methane sulfonic acid and estimates of $\mathrm{H}_{2} \mathrm{SO}_{4}$ production and loss in the atmosphere, J. Geophys. Res., 98, 9001-9010, doi:10.1029/93JD00031, 1993.

Eisele, F. L., Lovejoy, E. R., Kosciuch, E., Moore, K. F., Mauldin III, R. L., Smith, J. N., McMurry, P. H., and Iida, K.: Negative atmospheric ions and their potential role in ion-induced Nucleation, J. Geophys. Res., 111, D04305, doi:10.1029/2005JD006568, 2006.

Fiedler, V., Dal Maso, M., Boy, M., Aufmhoff, H., Hoffmann, J., Schuck, T., Birmili, W., Hanke, M., Uecker, J., Arnold, F., and Kulmala, M.: The contribution of sulphuric acid to atmospheric particle formation and growth: a comparison between boundary 
layers in Northern and Central Europe, Atmos. Chem. Phys., 5, 1773-1785, doi:10.5194/acp-5-1773-2005, 2005.

Forester, C. D. and Wells, J. R.: Hydroxyl radical yields from reactions of terpene mixtures with ozone, Indoor Air, 21, 400-409, doi:10.1111/j.1600-0668.2011.00718.x, 2011.

Freshour, N. A., Carlson, K. K., Melka, Y. A., Hinz, S., Panta, B., and Hanson, D. R.: Amine permeation sources characterized with acid neutralization and sensitivities of an amine mass spectrometer, Atmos. Meas. Tech., 7, 3611-3621, doi:10.5194/amt7-3611-2014, 2014.

Ge, X., Wexler, A. S., and Clegg, S. L.: Atmospheric amines - Part I, A review, Atmos. Environ., 45, 524-546, doi:10.1016/j.atmosenv.2010.10.012, 2011.

Geron, C., Rasmussen, R., Arnts, R. R., and Guenther, A.: A review and synthesis of monoterpene speciation from forests in the United States, Atmos. Environ., 34, 1761-1781, doi:10.1016/S1352-2310(99)00364-7, 2000.

Glasoe, W. A., Volz, K., Panta, B., Freshour, N., Bachman, R., Hanson, D. R., McMurry, P. H., and Jen, C.: Sulfuric acid nucleation: An experimental study of the effect of seven bases, J. Geophys. Res.-Atmos., 120, 1933-1950, doi:10.1002/2014JD022730, 2015.

Hamed, A., Korhonen, H., Sihto, S.-L., Joutsensaari, J., Järvinen, H., Petäjä, T., Arnold, F., Nieminen, T., Kulmala, M., Smith, J. N., Lehtinen, K. E. J., and Laaksonen, A.: The role of relative humidity in continental new particle formation, J. Geophys. Res., 116, D03202, doi:10.1029/2010JD014186, 2011.

Hanson, D. R. and Eisele, F. L.: Measurement of prenucleation molecular clusters in the $\mathrm{NH}_{3}, \mathrm{H}_{2} \mathrm{SO}_{4}, \mathrm{H}_{2} \mathrm{O}$ system, J. Geophys. Res., 107, D124158, doi:10.1029/2001JD001100, 2002.

Hanson, D. R. and Lovejoy, E. R.: Measurement of the thermodynamics of the hydrated dimer and trimer of sulfuric acid, J. Phys. Chem. A, 110, 9525-9528, doi:10.1021/jp062844w, 2006.

Hanson, D. R., McMurry, P. H., Jiang, J., Tanner, D., and Huey, L. G.: Ambient pressure proton transfer mass spectrometry: detection of amines and ammonia, Environ. Sci. Technol., 45, 88818888, doi:10.1021/es201819a, 2011.

Hellén, H., Kieloaho, A.-J., and Hakola, H.: Gas-phase alkyl amines in urban air; comparison with a boreal forest site and importance for local atmospheric chemistry, Atmos. Environ., 94, 192-197, doi:10.1016/j.atmosenv.2014.05.029, 2014.

Hirsikko, A., Laakso, L., Hõrrak, U., Aalto, P. P., Kerminen, V.M., and Kulmala, M.: Annual and size dependent variation of growth rates and ion concentrations in boreal forest, Boreal Environ. Res., 10, 357-369, 2005.

Heinritzi, M., Simon, M., Steiner, G., Wagner, A. C., Kürten, A., Hansel, A., and Curtius, J.: Characterization of the massdependent transmission efficiency of a CIMS, Atmos. Meas. Tech., 9, 1449-1460, doi:10.5194/amt-9-1449-2016, 2016.

Janson, R. and de Serves, C.: Acetone and monoterpene emissions from the boreal forest in northern Europe, Atmos. Environ., 35, 4629-4637, doi:10.1016/S1352-2310(01)00160-1, 2001.

Jen, C., McMurry, P. H., and Hanson, D. R.: Stabilization of sulfuric acid dimers by ammonia, methylamine, dimethylamine, and trimethylamine, J. Geophys. Res.-Atmos., 119, 7502-7514, doi:10.1002/2014JD021592, 2014.

Jen, C. N., Bachman, R., Zhao, J., McMurry, P. H., and Hanson, D. R.: Diamine-sulfuric acid reactions are a potent source of new particle formation, Geophys. Res. Lett., 43, 867-873, doi:10.1002/2015GL066958, 2016a.

Jen, C. N., Zhao, J., McMurry, P. H., and Hanson, D. R.: Chemical ionization of clusters formed from sulfuric acid and dimethylamine or diamines, Atmos. Chem. Phys., 16, 12513-12529, doi:10.5194/acp-16-12513-2016, 2016.

Jiang, J., Zhao, J., Chen, M., Eisele, F. L., Scheckman, J., Williams, B. J., Kuang, C., and McMurry, P. H.: First measurements of neutral atmospheric cluster and 1-2 nm particle number size distributions during nucleation events, Aerosol Sci. Technol., 45, ii-v, doi:10.1080/02786826.2010.546817, 2011.

Jokinen, T., Sipilä, M., Junninen, H., Ehn, M., Lönn, G., Hakala, J., Petäjä, T., Mauldin III, R. L., Kulmala, M., and Worsnop, D. R.: Atmospheric sulphuric acid and neutral cluster measurements using CI-APi-TOF, Atmos. Chem. Phys., 12, 4117-4125, doi:10.5194/acp-12-4117-2012, 2012.

Jokinen, T., Sipilä, M., Richters, S., Kerminen, V.-M., Paasonen, P., Stratmann, F., Worsnop, D., Kulmala, M., Ehn, M., Herrmann, H., and Berndt, T.: Rapid autooxidation forms highly oxidized $\mathrm{RO}_{2}$ radicals in the atmosphere, Angew. Chem. Int. Ed., 53, 14596-14600, doi:10.1002/anie.201408566, 2014.

Jokinen, T., Berndt, T., Makkonen, R., Kerminen, V.-M., Junninen, H., Paasonen, P., Stratmann, F., Herrmann, H., Guenther, A. B., Worsnop, D. R., Kulmala, M., Ehn, M., and Sipilä, M.: Production of extremely low volatile organic compounds from biogenic emissions: Measured yields and atmospheric implications, P. Natl. Acad. Sci. USA, 112, 7123-7128, doi:10.1073/pnas.1423977112, 2015.

Junninen, H., Ehn, M., Petäjä, T., Luosujärvi, L., Kotiaho, T., Kostiainen, R., Rohner, U., Gonin, M., Fuhrer, K., Kulmala, M., and Worsnop, D. R.: A high-resolution mass spectrometer to measure atmospheric ion composition, Atmos. Meas. Tech., 3, 10391053, doi:10.5194/amt-3-1039-2010, 2010.

Kirkby, J., Curtius, J., Almeida, J., Dunne, E., Duplissy, J., Ehrhart, S., Franchin, A., Gagné, S., Ickes, L., Kürten, A., Kupc, A., Metzger, A., Riccobono, F., Rondo, L., Schobesberger, S., Tsagkogeorgas, G., Wimmer, D., Amorim, A., Bianchi, F., Breitenlechner, M., David, A., Dommen, J., Downard, A., Ehn, M., Flagan, R.C., Haider, S., Hansel, A., Hauser, D., Jud, W., Junninen, H., Kreissl, F., Kvashin, A., Laaksonen, A., Lehtipalo, K., Lima, J., Lovejoy, E. R., Makhmutov, V., Mathot, S., Mikkilä, J., Minginette, P., Mogo, S., Nieminen, T., Onnela, A., Pereira, P., Petäjä, T., Schnitzhofer, R., Seinfeld, J. H., Sipilä, M., Stozhkov, Y., Stratmann, F., Tomé, A., Vanhanen, J., Viisanen, Y., Vrtala, A., Wagner, P. E., Walther, H., Weingartner, E., Wex, H., Winkler, P. M., Carslaw, K. S., Worsnop, D. R., Baltensperger, U., and Kulmala, M.: Role of sulphuric acid, ammonia and galactic cosmic rays in atmospheric aerosol nucleation, Nature, 476, 429-435, doi:10.1038/nature10343, 2011.

Kirkby, J., Duplissy, J., Sengupta, K., Frege, C., Gordon, H., Williamson, C., Heinritzi, M., Simon, M., Yan, C., Almeida, J., Tröstl, J., Nieminen, T., Ortega, I. K., Wagner, R., Adamov, A., Amorim, A., Bernhammer, A.-K., Bianchi, F., Breitenlechner, M., Brilke, S., Chen, X., Craven, J., Dias, A., Ehrhart, S., Flagan, R. C., Franchin, A., Fuchs, C., Guida, R., Hakala, J., Hoyle, C. R., Jokinen, T., Junninen, H., Kangasluoma, J., Kim, J., Krapf, M., Kürten, A., Laaksonen, A., Lehtipalo, K., Makhmutov, V., Mathot, S., Molteni, U., Onnela, A., Peräkylä, O., Piel, F., Petäjä, T., Praplan, A. P., Pringle, K., Rap, A., Richards, N. A. D., Riip- 
inen, I., Rissanen, M. P., Rondo, L., Sarnela, N., Schobesberger, S., Scott, C. E., Seinfeld, J. H., Sipilä, M., Steiner, G., Stozhkov, Y., Stratmann, F., Tomé, A., Virtanen, A., Vogel, A. L., Wagner, A., Wagner, P. E., Weingartner, E., Wimmer, D., Winkler, P. M., Ye, P., Zhang, X., Hansel, A., Dommen, J., Donahue, N. M., Worsnop, D. R., Baltensperger, U., Kulmala, M., Carslaw, K. S., and Curtius, J.: Ion-induced nucleation of pure biogenic particles, Nature, 533, 521-526, doi:10.1038/nature17953, 2016.

Kuang, C., McMurry, P. H., McCormick, A. V., and Eisele, F. L.: Dependence of nucleation rates on sulfuric acid vapor concentration in diverse atmospheric locations, J. Geophys. Res., 113, D10209, doi:10.1029/2007JD009253, 2008.

Kulmala, M., Vehkamäki, H., Petäjä, T., Dal Maso, M., Lauri, A., Kerminen, V.-M., Birmili, W., and McMurry, P. H.: Formation and growth rates of ultrafine atmospheric particles: a review of observations, J. Aerosol Sci., 35, 143-176, doi:10.1016/j.jaerosci.2003.10.003, 2004.

Kulmala, M., Petäjä, T., Nieminen, T,, Sipilä, M., Manninen, H. E., Lehtipalo, K., Dal Maso, M., Aalto, P. P., Junninen, H., Paasonen, P., Riipinen, I., Lehtinen, K. E. J., Laaksonen, A., and Kerminen, V.-M.: Measurement of the nucleation of atmospheric aerosol particles, Nat. Protoc., 7, 1651-1667, doi:10.1038/nprot.2012.091, 2012.

Kulmala, M., Kontkanen, J., Junninen, H., Lehtipalo, K., Manninen, H. E., Nieminen, T., Petäjä, T., Sipilä, M., Schobesberger, S., Rantala, P., Franchin, A., Jokinen, T., Järvinen, E., Äijälä, M., Kangasluoma, J., Hakala, J., Aalto, P. P., Paasonen, P., Mikkilä, J., Vanhanen, J., Aalto, J., Hakola, H., Makkonen, U., Ruuskanen, T., Mauldin III, R. L., Duplissy, J., Vehkamäki, H., Bäck, J., Kortelainen, A., Riipinen, I., Kurtén, T., Johnston, M. V., Smith, J. N., Ehn, M., Mentel, T. F., Lehtinen, K. E. J., Laaksonen, A., Kerminen, V.-M., and Worsnop, D. R.: Direct observations of atmospheric aerosol nucleation, Science, 339, 943-946, doi:10.1126/science.1227385, 2013.

Kürten, A., Rondo, L., Ehrhart, S., and Curtius, J.: Performance of a corona ion source for measurement of sulfuric acid by chemical ionization mass spectrometry, Atmos. Meas. Tech., 4, 437-443, doi:10.5194/amt-4-437-2011, 2011.

Kürten, A., Rondo, L., Ehrhart, S., and Curtius, J.: Calibration of a chemical ionization mass spectrometer for the measurement of gaseous sulfuric acid, J. Phys. Chem. A, 116, 6375-6386, doi:10.1021/jp212123n, 2012.

Kürten, A., Jokinen, T., Simon, M., Sipilä, M., Sarnela, N., Junninen, H., Adamov, A., Almeida, J., Amorim, A., Bianchi, F., Breitenlechner, M., Dommen, J., Donahue, N. M., Duplissy, J., Ehrhart, S., Flagan, R. C., Franchin, A., Hakala, J., Hansel, A., Heinritzi, M., Hutterli, M., Kangasluoma, J., Kirkby, J., Laaksonen, A., Lehtipalo, K., Leiminger, M., Makhmutov, V., Mathot, S., Onnela, A., Petäjä, T., Praplan, A. P., Riccobono, F., Rissanen, M. P., Rondo, L., Schobesberger, S., Seinfeld, J. H., Steiner, G., Tomé, A., Tröstl, J., Winkler, P. M., Williamson, C., Wimmer, D., Ye, P., Baltensperger, U., Carslaw, K. S., Kulmala, M., Worsnop, D. R., and Curtius, J.: Neutral molecular cluster formation of sulfuric acid-dimethylamine observed in real-time under atmospheric conditions, P. Natl. Acad. Sci. USA, 111, 1501915024, doi:10.1073/pnas.1404853111, 2014.

Kürten, A., Münch, S., Rondo, L., Bianchi, F., Duplissy, J., Jokinen, T., Junninen, H., Sarnela, N., Schobesberger, S., Simon, M., Sipilä, M., Almeida, J., Amorim, A., Dommen, J., Donahue, N. M.,
Dunne, E. M., Flagan, R. C., Franchin, A., Kirkby, J., Kupc, A., Makhmutov, V., Petäjä, T., Praplan, A. P., Riccobono, F., Steiner, G., Tomé, A., Tsagkogeorgas, G., Wagner, P. E., Wimmer, D., Baltensperger, U., Kulmala, M., Worsnop, D. R., and Curtius, J.: Thermodynamics of the formation of sulfuric acid dimers in the binary $\left(\mathrm{H}_{2} \mathrm{SO}_{4}-\mathrm{H}_{2} \mathrm{O}\right)$ and ternary $\left(\mathrm{H}_{2} \mathrm{SO}_{4}-\mathrm{H}_{2} \mathrm{O}-\mathrm{NH}_{3}\right)$ system, Atmos. Chem. Phys., 15, 10701-10721, doi:10.5194/acp15-10701-2015, 2015.

Kürten, A., Bianchi, F., Almeida, J., Kupiainen-Määttä, O., Dunne, E. M., Duplissy, J., Williamson, C., Barmet, P., Breitenlechner, M., Dommen, J., Donahue, N. M., Flagan, R. C., Franchin, A., Gordon, H., Hakala, J., Hansel, A., Heinritzi, M., Ickes, L., Jokinen, T., Kangasluoma, J., Kim, J., Kirkby, J., Kupc, A., Lehtipalo, K., Leiminger, M., Makhmutov, V., Onnela, A., Ortega, I. K., Petäjä, T., Praplan, A. P., Riccobono, F., Rissanen, M. P., Rondo, L., Schnitzhofer, R., Schobesberger, S., Smith, J. N., Steiner, G., Stozhkov, Y., Tomé, A., Tröstl, J., Tsagkogeorgas, G., Wagner, P. E., Wimmer, D., Ye, P., Baltensperger, U., Carslaw, K., Kulmala, M., and Curtius, J.: Experimental particle formation rates spanning tropospheric sulfuric acid and ammonia abundances, ion production rates and temperatures, J. Geophys. Res.Atmos., accepted, doi:10.1002/2015JD023908, 2016.

Kurtén, T., Loukonen, V., Vehkamäki, H., and Kulmala, M.: Amines are likely to enhance neutral and ion-induced sulfuric acid-water nucleation in the atmosphere more effectively than ammonia, Atmos. Chem. Phys., 8, 4095-4103, doi:10.5194/acp-8-4095-2008, 2008.

Lehtinen, K. E. J., Dal Maso, M., Kulmala, M., and Kerminen, V.-M.: Estimating nucleation rates from apparent particle formation rates and vice versa: Revised formulation of the Kerminen-Kulmala equation, J. Aerosol Sci., 38, 988-994, doi:10.1016/j.jaerosci.2007.06.009, 2007.

Lehtipalo, K., Rondo, L., Kontkanen, J., Schobesberger, S., Jokinen, T., Sarnela, N., Kürten, A., Ehrhart, S., Franchin, A., Nieminen, T., Riccobono, F., Sipilä, M., Yli-Juuti, T., Duplissy, J., Adamov, A., Ahlm, L., Almeida, J., Amorim, A., Bianchi, F., Breitenlechner, M., Dommen, J., Downard, A. J., Dunne, E. M., Flagan, R. C., Guida, R., Hakala, J., Hansel, A., Jud, W., Kangasluoma, J., Kerminen, V.-M., Keskinen, H., Kim, J., Kirkby, J., Kupc, A., Kupiainen-Määttä, O., Laaksonen, A., Lawler, M. J., Leiminger, M., Mathot, S., Olenius, T., Ortega, I. K., Onnela, A., Petäjä, T., Praplan, A., Rissanen, M. P., Ruuskanen, T., Santos, F. D., Schallhart, S., Schnitzhofer, R., Simon, M., Smith, J. N., Tröstl, J., Tsagkogeorgas, G., Tomé, A., Vaattovaara, P., Vehkamäki, H., Vrtala, A. E., Wagner, P. E., Williamson, C., Wimmer, D., Winkler, P. M., Virtanen, A., Donahue, N. M., Carslaw, K. S., Baltensperger, U., Riipinen, I., Curtius, J., Worsnop D. R., and Kulmala, M.: The effect of acid-base clustering and ions on the growth of atmospheric nano-particles, Nat. Commun., 7, 11594, doi:10.1038/ncomms11594, 2016.

Luts, A., Parts, T.-E., Hõrrak, U., Junninen, H., and Kulmala, M.: Composition of negative air ions as a function of ion age and selected trace gases: Mass- and mobility distribution, J. Aerosol Sci., 42 820-838, doi:10.1016/j.jaerosci.2011.07.007, 2011.

Mauldin III, R. L., Berndt, T., Sipilä, M., Paasonen, P., Petäjä, T., Kim, S., Kurtén, T., Stratmann, F., Kerminen, V.-M., and Kulmala, M.: A new atmospherically relevant oxidant of sulphur dioxide, Nature, 488, 193-196, doi:10.1038/nature11278, 2012. 
Merikanto, J., Spracklen, D. V., Mann, G. W., Pickering, S. J., and Carslaw, K. S.: Impact of nucleation on global CCN, Atmos. Chem. Phys., 9, 8601-8616, doi:10.5194/acp-9-8601-2009, 2009.

Metzger, A., Verheggen, B., Dommen, J., Duplissy, J., Prevot, A. S. H., Weingartner, E., Riipinen, I., Kulmala, M., Spracklen, D. V., Carslaw, K. S., and Baltensperger, U.: Evidence for the role of organics in aerosol particle formation under atmospheric conditions, P. Natl. Acad. Sci. USA, 107, 6646-6651, doi:10.1073/pnas.0911330107, 2010.

Mikkonen, S., Romakkaniemi, S., Smith, J. N., Korhonen, H., Petäjä, T., Plass-Duelmer, C., Boy, M., McMurry, P. H., Lehtinen, K. E. J., Joutsensaari, J., Hamed, A., Mauldin III, R. L., Birmili, W., Spindler, G., Arnold, F., Kulmala, M., and Laaksonen, A.: A statistical proxy for sulphuric acid concentration, Atmos. Chem. Phys., 11, 11319-11334, doi:10.5194/acp-11-11319-2011, 2011.

Monks, P. S.: Gas-phase radical chemistry in the troposphere, Chem. Soc. Rev., 34, 376-395, doi:10.1039/B307982C, 2005.

Mutzel, A., Poulain, L., Berndt, T., Iinuma, Y., Rodigast, M., Böge, O., Richters, S., Spindler, G., Sipilä, M., Jokinen, T., Kulmala, M., and Herrmann, H.: Highly oxidized multifunctional organic compounds observed in tropospheric particles: A field and laboratory study, Environ. Sci. Technol., 49, 7754-7761, doi:10.1021/acs.est.5b00885, 2015.

Nel, A.: Air pollution-related illness: Effects of particles, Science, 308, 804-806, doi:10.1126/science.1108752, 2005.

Nielsen, C. J., Herrmann, H., and Weller, C.: Atmospheric chemistry and environmental impact of the use of amines in carbon capture and storage (CCS), Chem. Soc. Rev., 41, 6684-6704, doi:10.1039/c2cs35059a, 2012.

Nieminen, T., Yli-Juuti, T., Manninen, H. E., Petäjä, T., Kerminen, V.-M., and Kulmala, M.: Technical note: New particle formation event forecasts during PEGASOS-Zeppelin Northern mission 2013 in Hyytiälä, Finland, Atmos. Chem. Phys., 15, 1238512396, doi:10.5194/acp-15-12385-2015, 2015.

Ortega, I. K., Kupiainen, O., Kurtén, T., Olenius, T., Wilkman, O., McGrath, M. J., Loukonen, V., and Vehkamäki, H.: From quantum chemical formation free energies to evaporation rates, Atmos. Chem. Phys., 12, 225-235, doi:10.5194/acp-12-225-2012, 2012.

Ortega, I. K., Olenius, T., Kupiainen-Määttä, O., Loukonen, V., Kurtén, T., and Vehkamäki, H.: Electrical charging changes the composition of sulfuric acid-ammonia/dimethylamine clusters, Atmos. Chem. Phys., 14, 7995-8007, doi:10.5194/acp-14-79952014, 2014.

Paasonen, P., Nieminen, T., Asmi, E., Manninen, H. E., Petäjä, T., Plass-Dülmer, C., Flentje, H., Birmili, W., Wiedensohler, A., Hõrrak, U., Metzger, A., Hamed, A., Laaksonen, A., Facchini, M. C., Kerminen, V.-M., and Kulmala, M.: On the roles of sulphuric acid and low-volatility organic vapours in the initial steps of atmospheric new particle formation, Atmos. Chem. Phys., 10, 11223-11242, doi:10.5194/acp-10-11223-2010, 2010.

Petäjä, T., Mauldin, III, R. L., Kosciuch, E., McGrath, J., Nieminen, T., Paasonen, P., Boy, M., Adamov, A., Kotiaho, T., and Kulmala, M.: Sulfuric acid and $\mathrm{OH}$ concentrations in a boreal forest site, Atmos. Chem. Phys., 9, 7435-7448, doi:10.5194/acp9-7435-2009, 2009.

Plane, J. M. C., Joseph, D. M., Allan, B. J., Ashworth, S. H., and Francisco, J. S.: An experimental and theoretical study of the reactions $\mathrm{OIO}+\mathrm{NO}$ and $\mathrm{OIO}+\mathrm{OH}$, J. Phys. Chem. A, 110, 93-100, doi:10.1021/jp055364y, 2006.

Praplan, A. P., Schobesberger, S., Bianchi, F., Rissanen, M. P., Ehn, M., Jokinen, T., Junninen, H., Adamov, A., Amorim, A., Dommen, J., Duplissy, J., Hakala, J., Hansel, A., Heinritzi, M., Kangasluoma, J., Kirkby, J., Krapf, M., Kürten, A., Lehtipalo, K., Riccobono, F., Rondo, L., Sarnela, N., Simon, M., Tomé, A., Tröstl, J., Winkler, P. M., Williamson, C., Ye, P., Curtius, J., Baltensperger, U., Donahue, N. M., Kulmala, M., and Worsnop, D. R.: Elemental composition and clustering behaviour of $\alpha$ pinene oxidation products for different oxidation conditions, Atmos. Chem. Phys., 15, 4145-4159, doi:10.5194/acp-15-41452015, 2015.

Rantala, P., Taipale, R., Aalto, J., Kajos, M. K., Patokoski, J., Ruuskanen, T. M., and Rinne, J.: Continuous flux measurements of VOCs using PTR-MS - reliability and feasibility of disjunct-eddy-covariance, surface-layer-gradient, and surfacelayer-profile methods, Boreal Environ. Res., 19, 87-107, 2014.

Riccobono, F., Schobesberger, S., Scott, C. E., Dommen, J., Ortega, I. K., Rondo, L., Almeida, J., Amorim, A., Bianchi, F., Breitenlechner, M., David, A., Downard, A., Dunne, E. M., Duplissy, J., Ehrhart, S., Flagan, R. C., Franchin, A., Hansel, A., Junninen, H., Kajos, M., Keskinen, H., Kupc, A., Kürten, A., Kvashin, A. N., Laaksonen, A., Lehtipalo, K., Makhmutov, V., Mathot, S., Nieminen, T., Onnela, A., Petäjä, T., Praplan, A. P., Santos, F. D., Schallhart, S., Seinfeld, J. H., Sipilä, M., Spracklen, D. V., Stozhkov, Y., Stratmann, F., Tomé, A., Tsagkogeorgas, G., Vaattovaara, P., Viisanen, Y., Vrtala, A., Wagner, P. E., Weingartner, E., Wex, H., Wimmer, D., Carslaw, K. S., Curtius, J., Donahue, N. M., Kirkby, J., Kulmala, M., Worsnop, D. R., and Baltensperger, U.: Oxidation products of biogenic emissions contribute to nucleation of atmospheric particles, Science, 344, 717721, doi:10.1126/science.1243527, 2014.

Rohrer, F. and Berreheim, H.: Strong correlation between levels of tropospheric hydroxyl radicals and solar ultraviolet radiation, Nature, 442, 184-187, doi:10.1038/nature04924, 2006.

Rondo, L., Kürten, A., Ehrhart, S., Schobesberger, S., Franchin, A., Junninen, H., Petäjä, T., Sipilä, M., Worsnop, D. R., and Curtius, J.: Effect of ions on the measurement of sulfuric acid in the CLOUD experiment at CERN, Atmos. Meas. Tech., 7, 38493859, doi:10.5194/amt-7-3849-2014, 2014.

Saiz-Lopez, A., Plane, J. M. C., Baker, A. R., Carpenter, L. J., von Glasow, R., Martín, J. C. G., McFiggans, G., and Saunders, R. W.: Atmospheric chemistry of iodine, Chem. Rev., 112, 17731804, doi:10.1021/cr200029u, 2012.

Saiz-Lopez, A., Baidar, S., Cuevas, C. A., Koenig, T. K., Fernandez, R. P., Dix, B., Kinnison, D. E., Lamarque, J.-F. , RodriguezLloveras, X., Campos, T. L., and Volkamer, R.: Injection of iodine to the stratosphere, Geophys. Res. Lett., 42, 6852-6859, doi:10.1002/2015GL064796, 2015.

Sarnela, N., Jokinen, T., Nieminen, T., Lehtipalo, K., Junninen, H., Kangasluoma, J., Hakala, J., Taipale, R., Schobesberger, S., Sipilä, M., Larnimaa, K., Westerholm, H., Heijari, J., Kerminen, V.M., Petäjä, T., and Kulmala, M.: Sulphuric acid and aerosol particle production in the vicinity of an oil refinery, Atmos. Environ., 119, 156-166, doi:10.1016/j.atmosenv.2015.08.033, 2015.

Sarwar, G., Fahey, K., Kwok, R., Gilliam, R. C., Roselle, S. J., Mathur, R., Xue, J., Yu, J., and Carter, W. P. L.: Potential impacts of two $\mathrm{SO}_{2}$ oxidation pathways on regional sulphate con- 
centrations: Aqueous-phase oxidation by $\mathrm{NO}_{2}$ and gas-phase oxidation by stabilized Criegee intermediate, Atmos. Environ., 68, 186-197, doi:10.1016/j.atmosenv.2012.11.036, 2013.

Schade, G. W. and Crutzen, P. J.: Emission of aliphatic amines from animal husbandry and their reactions: Potential source of $\mathrm{N}_{2} \mathrm{O}$ and $\mathrm{HCN}$, J. Atmos. Chem., 22, 319-346, doi:10.1007/BF00696641, 1995.

Schobesberger, S., Junninen, H., Bianchi, F., Lönn, G., Ehn, M., Lehtipalo, K., Dommen, J., Ehrhart, S., Ortega, I. K., Franchin, A., Nieminen, T., Riccobono, F., Hutterli, M., Duplissy, J., Almeida, J., Amorim, A., Breitenlechner, M., Downard, A. J., Dunne, E. M., Flagan, R. C., Kajos, M., Keskinen, H., Kirkby, J., Kupc, A., Kürten, A., Kurtén, T., Laaksonen, A., Mathot, S., Onnela, A., Praplan, A. P., Rondo, L., Santos, F. D., Schallhart, S., Schnitzhofer, R., Sipilä, M., Tomé, A., Tsagkogeorgas, G., Vehkamäki, H., Wimmer, D., Baltensperger, U., Carslaw, K. S., Curtius, J., Hansel, A., Petäjä, T., Kulmala, M., Donahue, N. M., and Worsnop, D. R.: Molecular understanding of atmospheric particle formation from sulfuric acid and large oxidized organic molecules, Proc. Natl. Acad. Sci. USA, 110, 1722317228, doi:10.1073/pnas.1306973110, 2013.

Sihto, S.-L., Kulmala, M., Kerminen, V.-M., Dal Maso, M., Petäjä, T., Riipinen, I., Korhonen, H., Arnold, F., Janson, R., Boy, M., Laaksonen, A., and Lehtinen, K. E. J.: Atmospheric sulphuric acid and aerosol formation: implications from atmospheric measurements for nucleation and early growth mechanisms, Atmos. Chem. Phys., 6, 4079-4091, doi:10.5194/acp-6-4079-2006, 2006.

Simon, M., Heinritzi, M., Herzog, S., Leiminger, M., Bianchi, F., Praplan, A., Dommen, J., Curtius, J., and Kürten, A.: Detection of dimethylamine in the low pptv range using nitrate chemical ionization atmospheric pressure interface time-of-flight (CI-APiTOF) mass spectrometry, Atmos. Meas. Tech., 9, 2135-2145, doi:10.5194/amt-9-2135-2016, 2016.

Sintermann, J., Schallhart, S., Kajos, M., Jocher, M., Bracher, A., Münger, A., Johnson, D., Neftel, A., and Ruuskanen, T.: Trimethylamine emissions in animal husbandry, Biogeosciences, 11, 5073-5085, doi:10.5194/bg-11-5073-2014, 2014.

Sipilä, M., Jokinen, T., Berndt, T., Richters, S., Makkonen, R., Donahue, N. M., Mauldin III, R. L., Kurtén, T., Paasonen, P., Sarnela, N., Ehn, M., Junninen, H., Rissanen, M. P., Thornton, J., Stratmann, F., Herrmann, H., Worsnop, D. R., Kulmala, M., Kerminen, V.-M., and Petäjä, T.: Reactivity of stabilized Criegee intermediates (sCIs) from isoprene and monoterpene ozonolysis toward SO2 and organic acids, Atmos. Chem. Phys., 14, 1214312153, doi:10.5194/acp-14-12143-2014, 2014.

Sipilä, M., Sarnela, N., Jokinen, T., Junninen, H., Hakala, J., Rissanen, M. P., Praplan, A., Simon, M., Kürten, A., Bianchi, F., Dommen, J., Curtius, J., Petäjä, T., and Worsnop, D. R.: Bisulfate - cluster based atmospheric pressure chemical ionization mass spectrometer for high-sensitivity $(<100 \mathrm{ppqV})$ detection of atmospheric dimethyl amine: proof-of-concept and first ambient data from boreal forest, Atmos. Meas. Tech., 8, 4001-4011, doi:10.5194/amt-8-4001-2015, 2015.
Stein, A. F., Draxler, R. R, Rolph, G. D., Stunder, B. J. B., Cohen, M. D., and Ngan, F.: NOAA's HYSPLIT atmospheric transport and dispersion modeling system, B. Am. Meteorol. Soc., 96, 2059-2077, doi:10.1175/BAMS-D-14-00110.1, 2015.

Tani, A., Hayward, S., and Hewitt, C. N.: Measurement of monoterpenes and related compounds by proton transfer reaction-mass spectrometry (PTR-MS), Int. J. Mass Spectrom., 223, 561-578, doi:10.1016/S1387-3806(02)00880-1, 2003.

Vanhanen, J. , Mikkilä, J. , Lehtipalo, K. , Sipilä, M. , Manninen, H. E. , Siivola, E. , Petäjä, T., and Kulmala, M.: Particle size magnifier for nano-CN detection, Aerosol Sci. Technol., 45, 533542, doi:10.1080/02786826.2010.547889, 2011.

von Bobrutzki, K., Braban, C. F., Famulari, D., Jones, S. K., Blackall, T., Smith, T. E. L., Blom, M., Coe, H., Gallagher, M., Ghalaieny, M., McGillen, M. R., Percival, C. J., Whitehead, J. D., Ellis, R., Murphy, J., Mohacsi, A., Pogany, A., Junninen, H., Rantanen, S., Sutton, M. A., and Nemitz, E.: Field inter-comparison of eleven atmospheric ammonia measurement techniques, Atmos. Meas. Tech., 3, 91-112, doi:10.5194/amt-3-91-2010, 2010.

Weber, R. J., Marti, J. J., McMurry, P. H., Eisele, F. L., Tanner, D. J., and Jefferson, A.: Measurements of new particle formation and ultrafine particle growth rates at a clean continental site, J. Geophys. Res., 102, 4375-4385, doi:10.1029/96JD03656, 1997.

You, Y., Kanawade, V. P., de Gouw, J. A., Guenther, A. B., Madronich, S., Sierra-Hernández, M. R., Lawler, M., Smith, J. N., Takahama, S., Ruggeri, G., Koss, A., Olson, K., Baumann, K., Weber, R. J., Nenes, A., Guo, H., Edgerton, E. S., Porcelli, L., Brune, W. H., Goldstein, A. H., and Lee, S.-H.: Atmospheric amines and ammonia measured with a chemical ionization mass spectrometer (CIMS), Atmos. Chem. Phys., 14, 12181-12194, doi:10.5194/acp-14-12181-2014, 2014.

$\mathrm{Yu}, \mathrm{H}$. and Lee, S.-H.: Chemical ionisation mass spectrometry for the measurement of atmospheric amines, Environ. Chem., 9, 190-201, doi:10.1071/EN12020, 2012.

Zhang, R., Khalizov, A., Wang, L., Hu, M., and Xu, W.: Nucleation and growth of nanoparticles in the atmosphere, Chem. Rev., 1957-2011, doi:10.1021/cr2001756, 2012.

Zhao, J., Eisele, F. L., Titcombe, M., Kuang, C., and McMurry, P. $\mathrm{H}$.: Chemical ionization mass spectrometric measurements of atmospheric neutral clusters using the cluster-CIMS, J. Geophys. Res., 115, D08205, doi:10.1029/2009JD012606, 2010.

Zhao, J., Smith, J. N., Eisele, F. L., Chen, M., Kuang, C., and McMurry, P. H.: Observation of neutral sulfuric acid-amine containing clusters in laboratory and ambient measurements, Atmos. Chem. Phys., 11, 10823-10836, doi:10.5194/acp-1110823-2011, 2011.

Zhao, J., Ortega, J., Chen, M., McMurry, P. H., and Smith, J. N.: Dependence of particle nucleation and growth on high-molecularweight gas-phase products during ozonolysis of $\alpha$-pinene, Atmos. Chem. Phys., 13, 7631-7644, doi:10.5194/acp-13-76312013, 2013. 